In cooperation with the Allegheny County Sanitary Authority and the Allegheny County Health Department

\title{
Fecal-Indicator Bacteria in the Allegheny, Monongahela, and Ohio Rivers and Selected Tributaries, Allegheny County, Pennsylvania, 2001-2005
}

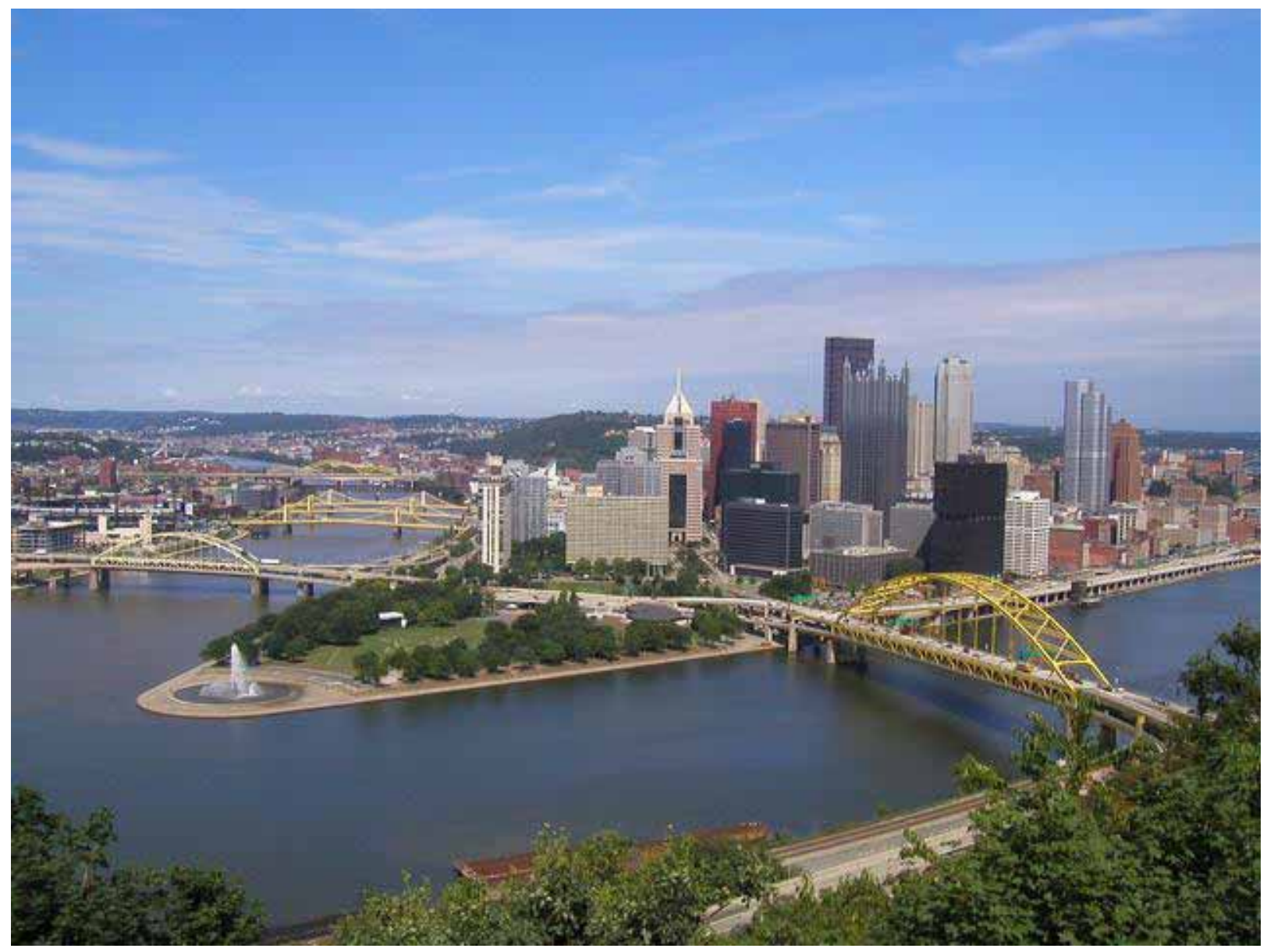

Scientific Investigations Report 2006-5216 
Cover. View of confluence of the Allegheny and Monongahela Rivers forming the Ohio River at Pittsburgh, Pennsylvania. (Photograph by Michael J. Langland, U.S. Geological Survey). 


\section{Fecal-Indicator Bacteria in the Allegheny, Monongahela, and Ohio Rivers and Selected Tributaries, Allegheny County, Pennsylvania, 2001-2005}

By Theodore F. Buckwalter, Tammy M. Zimmerman, and John W. Fulton

Scientific Investigations Report 2006-5216 


\section{U.S. Department of the Interior DIRK KEMPTHORNE, Secretary}

\section{U.S. Geological Survey \\ Mark D. Myers, Director}

\section{U.S. Geological Survey, Reston, Virginia 2006}

For product and ordering information:

World Wide Web: http://www.usgs.gov/pubprod

Telephone: 1-888-ASK-USGS

For more information on the USGS - the Federal source for science about the Earth, its natural and living resources, natural hazards, and the environment:

World Wide Web: http://www.usgs.gov

Telephone: 1-888-ASK-USGS

Any use of trade, product, or firm names is for descriptive purposes only and does not imply endorsement by the U.S. Government.

Although this report is in the public domain, permission must be secured from the individual copyright owners to reproduce any copyrighted material contained within this report.

Suggested citation:

Buckwalter, T.F., Zimmerman, T.M., and Fulton, J.W., 2006, Fecal-indicator bacteria in the Allegheny, Monongahela, and Ohio Rivers and selected tributaries, Allegheny County, Pennsylvania, 2001-2005:

U.S. Geological Survey Scientific Investigations Report 2006-5126, 27 p. 


\section{Contents}

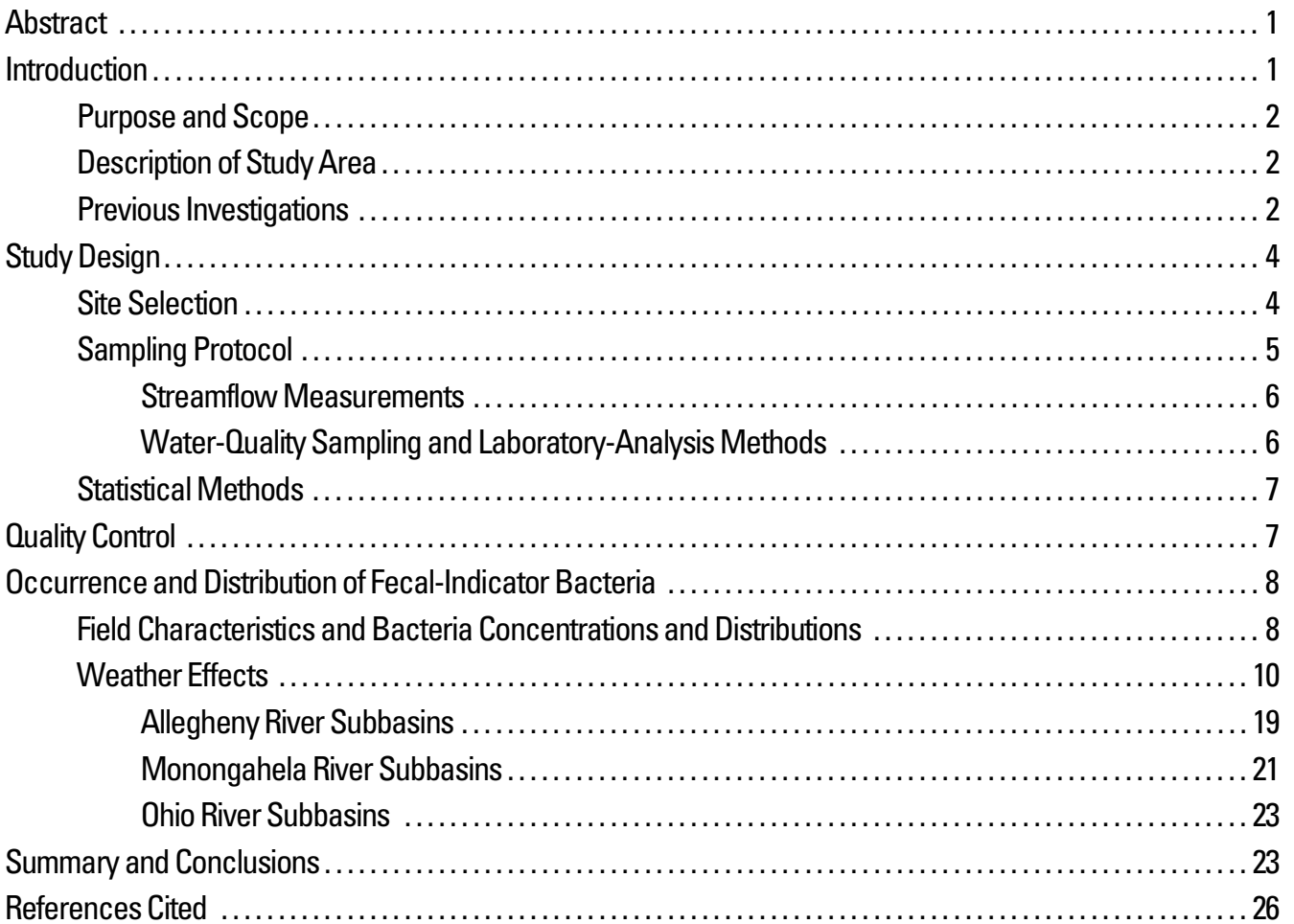

\section{Figures}

1. Map showing study area and location of water-sampling sites on the Allegheny, Monongahela, and Ohio Rivers and selected tributaries in Allegheny County, Pennsylvania........3

2. Graphs showing comparison of fecal-indicator bacteria colonies in composite samples collected during dry and wet weather on the Allegheny, Monongahela, and Ohio Rivers near Pittsburgh, Allegheny County, 2001-2005

3. Graphs showing fecal-indicator bacteria colonies in composite samples collected during dry and wet weather on Turtle Creek, Thompson Run, Sawmill Run, and Chartiers Creek, Allegheny County, 2004-2005.

4. Map showing concentrations of fecal-indicator bacteria in samples collected during dry weather on September 7, 2004, and wet weather on September 8, 9, and 10, 2004, from eight sites on Chartiers Creek, Sawmill Run, Thompson Run, and Turtle Creek, Allegheny County

5. Map showing locations of data-collection sites and sewer outfalls on the Allegheny River, Allegheny County ....

6. Map showing locations of data-collection sites and sewer outfalls within the Monongahela River, Turtle Creek, and Thompson Run watersheds, Allegheny County

7. Map showing locations of data-collection sites and sewer outfalls on the Ohio River and Chartiers Creek and Sawmill Run tributaries, Allegheny County. 


\section{Tables}

1. Pennsylvania fecal coliform standards and U.S. Environmental Protection Agency recommended criteria for indicator bacteria in colonies per 100 milliliters in recreational waters . . .4

2. Description of sampling sites on the Allegheny, Monongahela, and Ohio Rivers and

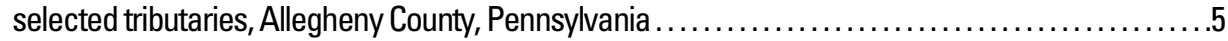

3. Description of streamflow-gaging stations on the Allegheny and Ohio Rivers and selected tributaries, Allegheny County ...

4. Summary statistics for streamflow, temperature, turbidity, and concentrations of fecalindicator bacteria for the five sampling sites on the Three Rivers, Allegheny County, 2001-2005 ....99

5. Summary statistics for streamflow, temperature, turbidity, and concentrations of fecalindicator bacteria for the eight sampling sites on Chartiers Creek, Sawmill Run, Thompson Run, and Turtle Creek, Allegheny County, 2004-2005

6. Summary of Spearman's rho correlations between fecal-indicator bacteria concentrations in water and field characteristics at the (A) Three Rivers sites and (B) select tributary sites near Pittsburgh, 2001-2005

7. Mean daily streamflows of tributary streams before and after the rainfall remnants of Hurricane Frances affected the streams of Allegheny County, September 7-10, 2004 . ...

8. Wilcoxon rank-sum comparison of sampling location differences in fecal-indicator bacteria and turbidity in dry-and wet-weather samples from five sites on the Allegheny, Monongahela, and Ohio Rivers, Allegheny County, 2001-2005.

\section{Conversion Factors and Datum}

\begin{tabular}{|c|c|c|}
\hline Multiply & By & To obtain \\
\hline \multicolumn{3}{|c|}{ Length } \\
\hline inch (in.) & 2.54 & centimeter $(\mathrm{cm})$ \\
\hline foot (ft) & 0.3048 & meter $(\mathrm{m})$ \\
\hline mile (mi) & 1.609 & kilometer (km) \\
\hline \multicolumn{3}{|c|}{ Area } \\
\hline square mile $\left(\mathrm{mi}^{2}\right)$ & 2.590 & square kilometer $\left(\mathrm{km}^{2}\right)$ \\
\hline milliliter $(\mathrm{mL})$ & .06102 & cubic inch $\left(\right.$ in $\left.^{3}\right)$ \\
\hline \multicolumn{3}{|c|}{ Flow rate } \\
\hline Liter (L) & 0.2642 & gallon (gal) \\
\hline cubic foot per second $\left(\mathrm{ft}^{3} / \mathrm{s}\right)$ & 0.02832 & cubic meters per second $\left(\mathrm{m}^{3} / \mathrm{s}\right)$ \\
\hline
\end{tabular}

Temperature in degrees Celsius $\left({ }^{\circ} \mathrm{C}\right)$ may be converted to degrees Fahrenheit $\left({ }^{\circ} \mathrm{F}\right)$ as follows:

$$
{ }^{\circ} \mathrm{F}=\left(1.8 \times{ }^{\circ} \mathrm{C}\right)+32
$$

Temperature in degrees Fahrenheit $\left({ }^{\circ} \mathrm{F}\right)$ may be converted to degrees Celsius $\left({ }^{\circ} \mathrm{C}\right)$ as follows:

$$
{ }^{\circ} \mathrm{C}=\left({ }^{\circ} \mathrm{F}-32\right) / 1.8
$$

Turbidity measurements are given in Nephelometric turbidity units (NTU).

Concentrations of bacteria in water are given in colonies per 100 milliliters (col/100 mL), which is the same as colony forming units per 100 milliliters (CFU/100 mL). 


\title{
Fecal-Indicator Bacteria in the Allegheny, Monongahela, and Ohio Rivers and Selected Tributaries, Allegheny County, Pennsylvania, 2001-2005
}

\author{
By Theodore F. Buckwalter, Tammy M. Zimmerman, and John W. Fulton
}

\section{Abstract}

Concentrations of fecal-indicator bacteria were determined in 1,027 water-quality samples collected from July 2001 through August 2005 during dry- (72-hour dry antecedent period) and wet-weather (48-hour dry antecedent period and at least 0.3 inch of rain in a 24-hour period) conditions in the Allegheny, Monongahela, and Ohio Rivers (locally referred to as the Three Rivers) and selected tributaries in Allegheny County. Samples were collected at five sampling sites on the Three Rivers and at eight sites on four tributaries to the Three Rivers having combined sewer overflows.

Water samples were analyzed for three fecal-indicator organisms-fecal coliform, Escherichia coli (E. coli), and enterococci bacteria. Left-bank and right-bank surface-water samples were collected in addition to a cross-section composite sample at each site.

Concentrations of fecal coliform, E. coli, and enterococci were detected in 98.6, 98.5, and 87.7 percent of all samples, respectively. The maximum fecal-indicator bacteria concentrations were collected from Sawmill Run, a tributary to the Ohio River; Sawmill Run at Duquesne Heights had concentrations of fecal coliform, E. coli, and enterococci of 410,000, 510,000, and $180,000 \mathrm{col} / 100 \mathrm{~mL}$, respectively, following a large storm.

The samples collected in the Three Rivers and selected tributaries frequently exceeded established recreational standards and criteria for bacteria. Concentrations of fecal coliform exceeded the Pennsylvania water-quality standard (200 col/100 mL) in approximately 63 percent of the samples. Sample concentrations of $E$. coli and enterococci exceeded the U.S. Environmental Protection Agency (USEPA) water-quality criteria ( 235 and $61 \mathrm{col} / 100 \mathrm{~mL}$, respectively) in about 53 and 47 percent, respectively, of the samples.

Fecal-indicator bacteria were most strongly correlated with streamflow, specific conductance, and turbidity. These correlations most frequently were observed in samples collected from tributary sites. Fecal-indicator bacteria concentrations and turbidity were correlated to the location of sample collection in the cross section. Most differences were between bank and composite samples; differences between right-bank and left-bank samples were rarely observed. The Allegheny
River sites had more significant correlations than the Monongahela or Ohio River sites.

Comparisons were made between fecal-indicator bacteria in composite samples collected during dry-weather, wetweather day-one, wet-weather day-two (tributary sites only), and wet-weather day-three (Three Rivers sites only) events in the Three Rivers and selected tributary sites. The lowest median bacteria concentrations generally were observed in the dryweather composite samples. All median bacteria concentrations in dry-weather composite samples in the five Three Rivers sites were below water-quality standards and criteria; bacteria concentrations in the upstream tributary sites rarely met all standards or criteria. Only Turtle Creek, Thompson Run, and Chartiers Creek had at least one median bacteria concentration below water-quality standards or criteria. Median bacteria concentrations in the composite samples generally were higher the day after a wet-weather event compared to dry-weather composite samples and other wet-weather composite samples collected. In the five Three Rivers sites, median bacteria concentrations 3 days after a wet-weather event in composite samples tended to fall below the water-quality standards and criteria; in the eight tributary sites, median bacteria concentrations in the dry-weather and wet-weather composite samples generally were above the water-quality standards or criteria. Composite samples collected at the upstream sites on the Three Rivers and selected tributaries generally had lower median bacteria concentrations than composite samples collected at the downstream sites during dry- and wet-weather events. Higher concentrations downstream may be because of the large number of sewer outfalls in the reach between the upstream and downstream sites.

\section{Introduction}

Exposure to pathogens (disease-causing organisms) in water can have adverse effects on humans. During contact with recreational water, excessive amounts of these organisms (for example, pathogenic bacteria and viruses) can increase the risk of gastrointestinal, respiratory, eye, ear, throat, and skin diseases. Drinking water containing pathogens also may pose a risk, but public-water supplies must pass state drinking-water 


\section{Fecal-Indicator Bacteria in the Allegheny, Monongahela, and Ohio Rivers and Selected Tributaries, 2001-2005}

standards prior to distribution. Most pathogens can be removed by the use of chlorination, ion exchange, filtration, and reverse osmosis.

Because individual pathogens are difficult to detect and measure directly (Chapra, 1997, p. 504), monitoring programs commonly rely on the detection of indicator organisms as a surrogate of water quality. If indicator organisms (nonpathogenic) are present, it is assumed that more harmful pathogenic bacteria, viruses, and protozoans may coexist in the water body. Fecal-indicator bacteria generally include a variety of coliform bacteria and streptococcus bacteria. Traditionally, fecal coliform has been the most widely used fecal-indicator bacteria for monitoring; however, its use is problematic because not all fecal coliform bacteria are fecal in origin. Enterococci and Escherichia coli (E. coli) originate solely in the intestines of warm-blooded animals and provide direct evidence of fecal contamination. Each can be sampled and quantified using standard methods and are relatively abundant in human and animal waste. Because the die-off rates for enterococci and E. coli are less than that of fecal coliform, they provide a better measure of the risk of gastrointestinal illness related to recreational contact with water (U.S. Environmental Protection Agency, 2001).

Federal regulations require public notice when sewer overflows and runoff increase the likelihood of river contamination. Since 1995, the Allegheny County Health Department (ACHD) has issued river-water advisories to warn of possible river contamination and to caution people to limit contact with river water when boating, fishing, water skiing, swimming, or engaging in other river recreational activities. An advisory does not prohibit nor discourage river recreational activities; instead, it is intended to inform the public when river water may be contaminated so that precautions can be taken to minimize water contact. Advisories are issued as warranted during the summer river-recreation season, which lasts from approximately May 15 to September 30, when sewer overflows and storm runoff increase the likelihood of river contamination. During the summer of 2000, when precipitation was above normal, 13 advisories were issued, lasting 71 out of a total of 138 days.

Bacteria concentrations in water samples collected from the Allegheny, Monongahela, and Ohio Rivers near Pittsburgh, $\mathrm{Pa}$. (referred to hereafter as Three Rivers), were measured to evaluate the recreational quality of the Three Rivers and the effects of wet weather on bacteria concentrations. The U.S. Geological Survey (USGS), in cooperation with the ACHD, began a project in July 2001 to assess concentrations of fecalindicator bacteria of the Three Rivers in Allegheny County, Pa. The project was supported by funds allocated through Section 104(b) (3) of the Clean Water Act (CWA) and administered by the U.S. Environmental Protection Agency (USEPA) and the Pennsylvania Department of Environmental Protection (PaDEP). From 2002 through 2005, the project was cooperatively funded by the Allegheny County Sanitary Authority (ALCOSAN) and the USGS, and the scope of the study was expanded to include selected tributaries to the Three Rivers. The ACHD provided laboratory analysis for fecal-indicator bacteria throughout the study period (from 2001 through 2005).

\section{Purpose and Scope}

This report presents and describes results of analyses of E. coli, enterococci, and fecal coliform bacteria data in water samples collected from five sites on the Three Rivers from 2001 through 2005 (generally June to October each year to coincide with heavy recreational use of the rivers) and from eight sites on four tributary streams from August 2004 through July 2005. The report also describes the effect of weather on bacteria concentrations by comparing the distribution of bacteria in the Three Rivers and four tributaries in left-bank, right-bank, and composite samples during dry- and wet-weather conditions. Water samples were collected and streamflow was measured during dry- and wet-weather conditions at all five sampling sites on the Three Rivers and at all eight sites on four tributary streams in Allegheny County. During wet-weather conditions, water samples were collected on day one, day two (tributary sites only), day three, and day five after an event at the Three Rivers sites and at the tributary sites.

\section{Description of Study Area}

The study area includes the Allegheny, Monongahela, and Ohio River Basins within Allegheny County (fig. 1). Allegheny County encompasses an area of about $730 \mathrm{mi}^{2}$. Pittsburgh, the county seat, is near the center of the county, where the Allegheny and Monongahela Rivers join to form the Ohio River.

The Allegheny River serves as the source of water supply for the City of Pittsburgh. The Allegheny River is also the source of water for the Wilkinsburg-Penn Joint Water Authority, serving areas in Allegheny County to the east and northeast of the City of Pittsburgh. The Monongahela River is the source of water for the Pennsylvania American Water Company, serving large areas of Allegheny County to the south of the city of Pittsburgh. The Ohio River is the source of water supply for the West View Water Authority, serving a large population north of the Ohio River in Allegheny County.

\section{Previous Investigations}

Previous studies have described fecal-indicator bacteria concentrations in the Three Rivers area. A report by Fulton and Buckwalter (2004) presents the findings of a bacteriological study conducted July - September 2001, in the Three Rivers. Fulton and Buckwalter (2004) also documented bacteriological investigations by the Ohio River Valley Water Sanitation Commission (ORSANCO), USGS, and local efforts in 2004 and prior to 2004.

In 2005, a comprehensive report was published on water resources, water quality, and causes of water-quality impairment in southwestern Pennsylvania that included data from numerous sources such as water treatment plants, ACHD, USGS, U.S. Army Corps of Engineers, schools, and independent studies (Committee on Water Quality Improvement for the Pittsburgh Region, 2005). The report documented concentra- 


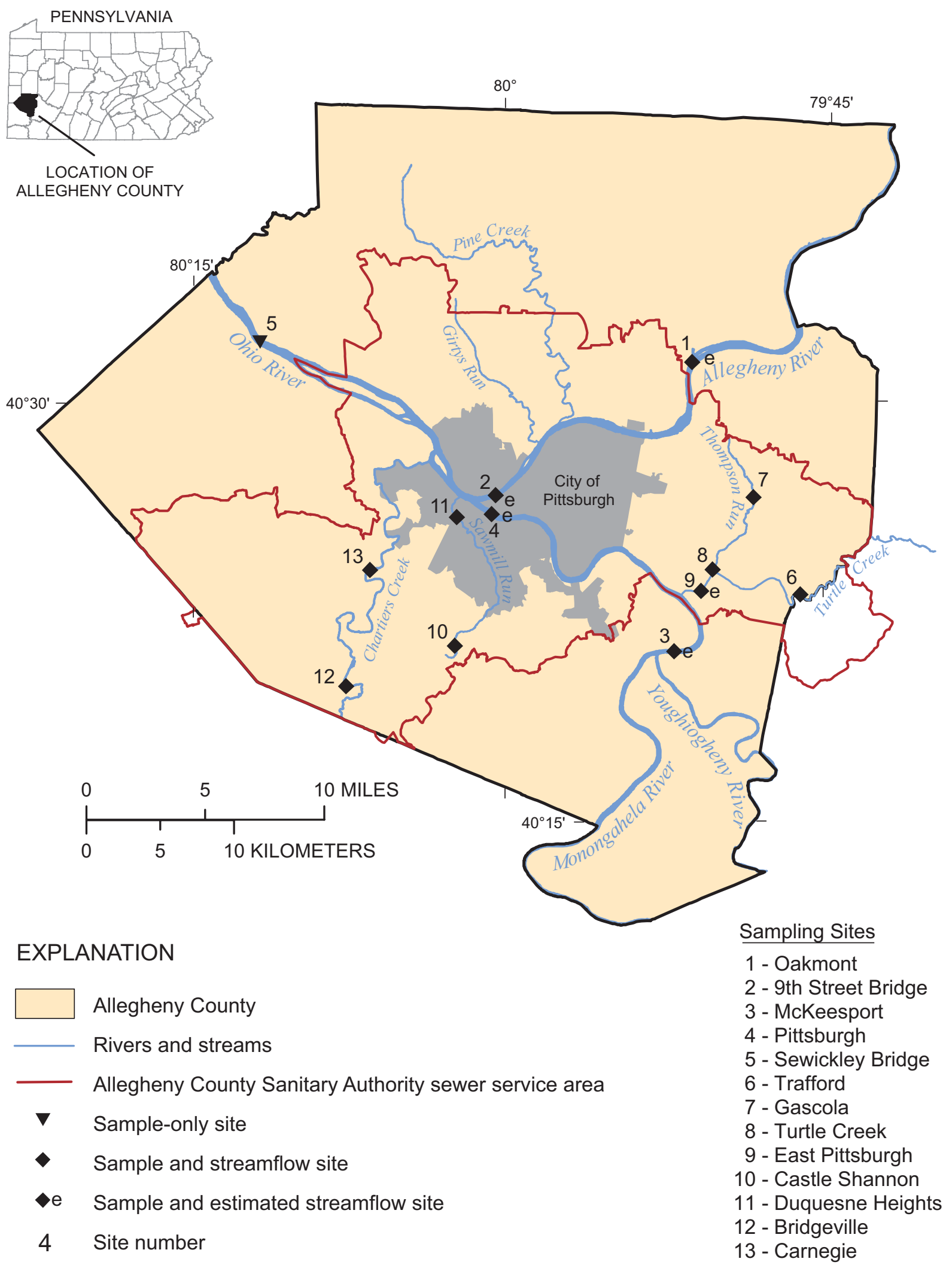

Figure 1. Study area and location of water-sampling sites on the Allegheny, Monongahela, and Ohio Rivers and selected tributaries in Allegheny County, Pennsylvania. 


\section{Fecal-Indicator Bacteria in the Allegheny, Monongahela, and Ohio Rivers and Selected Tributaries, 2001-2005}

tions of E. coli, enterococci, and fecal coliform as well as Cryptosporidium and Giardia in the Three Rivers and selected tributaries.

Locally, other studies have documented the presence of fecal-indicator bacteria in rivers, streams, and wastewaters also found to be contaminated with the waterborne, pathogenic protozoans Giardia and Cryptosporidium. For example, a study in Allegheny County by States and others (1997) found Giardia present in water samples collected 1994-1997 from the Allegheny and Youghiogheny Rivers. The relevance of the documented presence of pathogens in surface waters in the Three Rivers area is that recreational contact with these waters carries the risk of contracting illnesses and the presence of nonpathogenic fecal-indicator bacteria (E. coli, enterococci, and fecal coliform) may indicate when that risk is greater.

\section{Study Design}

The study was designed to characterize bacteria concentrations in the rivers (Three Rivers) entering and exiting Allegheny County. Additionally, it was important to establish the bacteria contributions of the Allegheny and Monongahela Rivers because of the large number of sewer outfalls discharging to each of the rivers prior to their discharging to the Ohio River. Bacteria concentrations of selected tributaries also were characterized because of the large number of sewer outfalls discharging to Three Rivers tributary streams.

Bacteria concentrations from samples collected in the Three Rivers and selected tributaries were compared to established standards and criteria. Public health standards have been established to assess the microbiological quality of recreational waters. The Pennsylvania water-quality standards for fecal coliform in recreational waters and the USEPA recommended criteria for $E$. coli and enterococci are shown in table 1 (Pennsylvania Code, 25 PaCode $\S 93.7$; U.S. Environmental Protection Agency, 1986). The USEPA single-sample bathing-water criteria for $E$. coli and enterococci were used as human-health benchmarks in analyzing the data for this study. Pennsylvania has no single-sample bathing-water standard for fecal coliform, but instead uses a 30-day geometric mean. Samples for this study were not collected at each site at the frequency needed to calculate a 30-day geometric mean so, for this report, the standard of $200 \mathrm{col} / 100 \mathrm{~mL}$ was used for comparison purposes only. A 30-day geometric mean for fecal coliform was not calculated but rather, the frequency of samples exceeding $200 \mathrm{col} / 100 \mathrm{~mL}$ will be described.

\section{Site Selection}

Water samples and streamflow data were collected from five sites on the Three Rivers-Allegheny River at Oakmont, Allegheny River at 9th Street Bridge, Monongahela River at McKeesport, Monongahela River at Pittsburgh, and Ohio River at Sewickley (fig. 1) (table 2). The Allegheny River at Oakmont was sampled because it was near the boundary of the ALCOSAN service area. The Allegheny River at 9th Street Bridge and Monongahela River at Pittsburgh were sampled to estimate the contributions of fecal-indicator bacteria from these rivers to the Ohio River. The Monongahela River at McKeesport was sampled to coincide with the upstream boundary of the ALCOSAN service area. The Ohio River at Sewickley was sampled because it is an active USGS water-quality site (Siwicki, 2005) near the downstream boundary of the ALCOSAN service area. The streamflow-gaging station associated with this site is $1.5 \mathrm{mi}$ downstream at a U.S. Army Corps. of Engineers Lock and Dam and represents the Ohio River as it flows out of Allegheny County.

Table 1. Pennsylvania fecal coliform standards and U.S. Environmental Protection Agency recommended criteria for indicator bacteria in colonies per 100 milliliters in recreational waters.

[--, no established standard or criteria]

\begin{tabular}{|c|c|c|c|c|}
\hline \multirow{2}{*}{$\begin{array}{l}\text { Indicator } \\
\text { bacteria }\end{array}$} & \multirow{2}{*}{$\begin{array}{c}\text { Timeframe } \\
\text { standards } \\
\text { apply }\end{array}$} & \multirow{2}{*}{$\begin{array}{c}\begin{array}{c}\text { Pennsylvania } \\
\text { bacteria } \\
\text { standards }^{1}\end{array} \\
\begin{array}{c}\text { 30-day geometric } \\
\text { mean }\end{array}\end{array}$} & \multicolumn{2}{|c|}{$\begin{array}{l}\text { U.S. Environmental Protection } \\
\text { Agency criteria }{ }^{2}\end{array}$} \\
\hline & & & $\begin{array}{l}\text { 30-day geometric } \\
\text { mean }\end{array}$ & $\begin{array}{l}\text { Single-sample } \\
\text { maximum }\end{array}$ \\
\hline \multirow[t]{2}{*}{ Fecal coliform } & May 1 to September 30 & 200 & -- & -- \\
\hline & October 1 to April 30 & 2,000 & -- & -- \\
\hline Escherichia coli & year round & -- & 126 & 235 \\
\hline Enterococci & year round & -- & 33 & 61 \\
\hline
\end{tabular}

\footnotetext{
${ }^{1}$ Pennsylvania Code (25 PaCode § 93.7).

${ }^{2}$ U.S. Environmental Protection Agency, 1986.
} 
Table 2. Description of sampling sites on the Allegheny, Monongahela, and Ohio Rivers and selected tributaries, Allegheny County, Pennsylvania.

[Note: sites are listed in downstream-order number; NA, not applicable]

\begin{tabular}{|c|c|c|c|c|c|}
\hline $\begin{array}{c}\text { Site } \\
\text { name }\end{array}$ & $\begin{array}{c}\text { Site } \\
\text { number }\end{array}$ & $\begin{array}{l}\text { U.S. Geological } \\
\text { Survey site } \\
\text { identification } \\
\text { number }\end{array}$ & $\begin{array}{c}\text { Sample obtained } \\
\text { from }\end{array}$ & $\begin{array}{c}\text { River mile } \\
\text { (miles) }\end{array}$ & $\begin{array}{l}\text { Drainage area } \\
\text { (square miles) }\end{array}$ \\
\hline \multicolumn{6}{|c|}{ Allegheny, Monongahela, and Ohio Rivers } \\
\hline Allegheny River at Oakmont & 1 & 03049652 & bridge & ${ }^{1} 12.7$ & 11,600 \\
\hline Allegheny River at 9th Street Bridge & 2 & 03049832 & boat & ${ }^{1} .7$ & 11,700 \\
\hline Monongahela River at Pittsburgh & 4 & 03085150 & boat & ${ }^{2} .8$ & 7,370 \\
\hline Ohio River at Sewickley (Sewickley bridge) & 5 & -- & bridge & ${ }^{3} 11.8$ & About 19,500 \\
\hline \multicolumn{6}{|c|}{ Monongahela River tributaries } \\
\hline Turtle Creek at Trafford & 6 & 03084400 & wading, bridge & NA & 55.5 \\
\hline \multicolumn{6}{|c|}{$\underline{\text { Ohio River tributaries }}$} \\
\hline Sawmill Run at Castle Shannon & 10 & 03085160 & wading, bridge & NA & 1.04 \\
\hline Sawmill Run at Duquesne Heights near Pittsburgh & 11 & 03085213 & wading, bridge & NA & 18.1 \\
\hline Chartiers Creek near Bridgeville & 12 & 03085290 & wading, bridge & NA & 160 \\
\hline Chartiers Creek at Carnegie & 13 & 03085500 & wading, bridge & NA & 257 \\
\hline
\end{tabular}

Water samples also were collected at eight tributary sites-Turtle Creek at Trafford, Thompson Run at Gascola, Thompson Run at Turtle Creek, Turtle Creek at East Pittsburgh, Sawmill Run at Castle Shannon, Sawmill Run at Duquesne Heights, Chartiers Creek near Bridgeville, and Chartiers Creek at Carnegie (fig. 1) (table 2). Turtle Creek and Thompson Run (headwaters in Westmoreland and Allegheny Counties, respectively) are tributaries to the Monongahela River; Sawmill Run and Chartiers Creek (headwaters in Allegheny and Washington Counties, respectively) are tributaries to the Ohio River. Water samples were collected on the tributaries discharging to the Three Rivers so that bacteria contributions could be evaluated and concentrations could be compared to recreational standards and criteria. The sites were selected as sampling locations by ALCOSAN because of the presence of numerous sewer outfalls on the tributaries. Two sites were selected on each of the four tributaries including an upstream site and a downstream site. The upstream sites were near the boundary of the ALCOSAN service area, and the downstream sites were at the location of an existing streamflow-gaging station except for Turtle Creek at East Pittsburgh. The streamflow at Turtle Creek at East Pittsburgh was estimated.

\section{Sampling Protocol}

Development of the sampling protocols to measure fecalindicator bacteria in the Three Rivers included considerations for wet- and dry-weather conditions. The study adopted the definition of dry-weather conditions and a modified version of the definition of wet-weather conditions established by ORSANCO (Ohio River Water Sanitation Commission, 2006). A dryweather event is characterized by at least a 72-hour dry antecedent period; a wet-weather event is characterized by at least a 48hour dry antecedent period and at least $0.3 \mathrm{in}$. of precipitation in a 24-hour period (this time period is an expansion to 24 hours from the original ORSANCO (2006) definition of 6 hours for a wet-weather event). Dry-weather samples generally were collected every time the dry-weather criterion was met. Wetweather samples were collected on day one, day two (tributary sites only), day three, and day five after an event at the Three Rivers sites and at the selected tributary sites. The wet-weather criterion was sometimes violated in day-three samples collected at tributary sites; for this reason, results of day-three samples at the tributaries will not be discussed in this report. If the concentrations of fecal-indicator bacteria were less than water-quality standards or criteria on day three, the day-five sample was not 


\section{Fecal-Indicator Bacteria in the Allegheny, Monongahela, and Ohio Rivers and Selected Tributaries, 2001-2005}

collected. Additionally, samples were collected only after wetweather events that encompassed large parts of Allegheny County.

Equal discharge-increment (EDI) sampling and grab sampling were utilized at each sampling site on the Three Rivers. For each sampling event, three samples were collected at each site, one composite sample to represent water quality of the entire channel cross-section (EDI sample) and two grab samples to represent water quality in recreational-use areas near the shoreline--one sample near the left bank, and one sample near the right bank (about $20 \mathrm{ft}$ from the shoreline). EDI samples provide an advantage over conventional grab samples in that they represent an integrated discharge-weighted sample. As a result, the concentration reported can be used in conjunction with the flow rate measured at the section to determine the load at the time of sampling. Details describing the EDI method are described by USGS (1997 to present).

Collection of EDI samples was not practical at the sampling sites on tributary streams because the streamflows sometimes changed dramatically within a few minutes during wetweather events (U.S. Geological Survey, 2006). To obtain representative samples in tributary streams, standardized equalwidth-increment (EWI) methods were used (U.S. Geological Survey, 1997 to present). For the EWI method, the stream cross section is divided into a number of equal-width increments instead of a number of equal-discharge increments.

\section{Streamflow Measurements}

Streamflow either was measured by a network of streamflow-gaging stations (table 3 ) or was estimated. Streamflow data usually were obtained at the same site where water-quality samples were collected with two exceptions. At the Ohio River at Sewickley, samples were collected from the Sewickley Bridge at River mile 11.8. The streamflow at Turtle Creek at East Pittsburgh was estimated by adding the streamflow from the Thompson Run at Turtle Creek gaging station and the streamflow from the Turtle Creek at Wilmerding gaging station and applying a correction factor for the small ungaged part of Turtle Creek between Wilmerding and East Pittsburgh.

The EDI sample locations at the Three Rivers sites without continuous-record streamflow-gaging stations were established using streamflow measurements made at each cross section (Allegheny River at 9th Street Bridge, Monongahela River at Pittsburgh, and Monongahela River at McKeesport). Streamflow measurements were made at the time of water-quality sampling using an acoustic Doppler current profiler (ADCP) (Oberg and others, 2005). Velocity-distribution data were reviewed to establish appropriate EDI sample locations at the Three Rivers stations (Ohio River at Sewickley; Allegheny River at Oakmont — estimates determined from the Allegheny River at Natrona) (table 3).

Stage-discharge relations were developed at gaging stations on selected tributaries and the Ohio River at Sewickley (table 3) using standardized techniques described in Rantz
(1982). Streamflow and corresponding stage were measured at low, medium, high, and flood stages to allow for the estimation of streamflow for any given stage.

Streamflows at the time of water-quality sampling generally were estimated from continuous-record streamflow-gaging stations upstream from sites 1, 2, 3, 4, and 9. These estimated streamflow sites are denoted with a letter "e" on figure 1 and on subsequent figures in this report.

Hydrographs ideally could be developed and reviewed for each site and samples could be collected to coincide with a point on the rising limb, at peak flow, and on the falling limb of the hydrograph. However, river flows are highly regulated by flood-control dams within the Three Rivers region, and water is withdrawn for power generation and water supply. As a result of these regulated flows, rapid fluctuations in discharge of several thousand cubic feet per second are common during dry- and wet-weather periods on the Three Rivers. Therefore, the sampling protocol was set at fixed time intervals following wetweather events instead of by sampling over the hydrograph.

\section{Water-Quality Sampling and Laboratory-Analysis Methods}

Water samples were collected at the five Three Rivers sites from 2001 through 2005 (June to October 2001-2004, June to August 2005) and at eight sites on four tributaries to the Three Rivers (June 2004 - July 2005). All water samples were analyzed for the following constituents using methodologies consistent with those referenced in the National Field Manual for the Collection of Water-Quality Data (U.S. Geological Survey, 1997 to present): (1) fecal coliform bacteria, (2) E. coli bacteria, (3) enterococci bacteria, (4) turbidity, (5) specific conductance, (6) temperature, (7) dissolved oxygen, and (8) $\mathrm{pH}$.

Aseptic techniques were maintained for collection of water samples for analysis of fecal-indicator bacteria, and sterile containers and equipment were used during sampling. Water samples for analysis of fecal-indicator bacteria were packed in ice and transported within the 6-hour holding time to the ACHD Laboratory for analysis as required by USGS (1997 to present) and the USEPA (1999).

Laboratory staff of the ACHD determined fecal-indicator bacteria concentrations using membrane-filtration techniques for approved methods for bacteriological enumeration. Fecal coliform bacteria concentrations were determined using procedures from Standard Methods for the Examination of Water and Wastewater by the American Public Health Association and others (1998, p. 9-63 to 9-65). Concentrations of enterococci bacteria were determined using standard methods described in American Public Health Association and others (1998, p. 9-76 to 9-78). The method used for E. coli bacteria (Method 1103.1 using mTEC Agar) was that of the USEPA (2000, p. 24-35). 
Table 3. Description of streamflow-gaging stations on the Allegheny and Ohio Rivers and selected tributaries, Allegheny County, Pennsylvania.

[--, not applicable; NA, not applicable; ALCOSAN, Allegheny County Sanitary Authority]

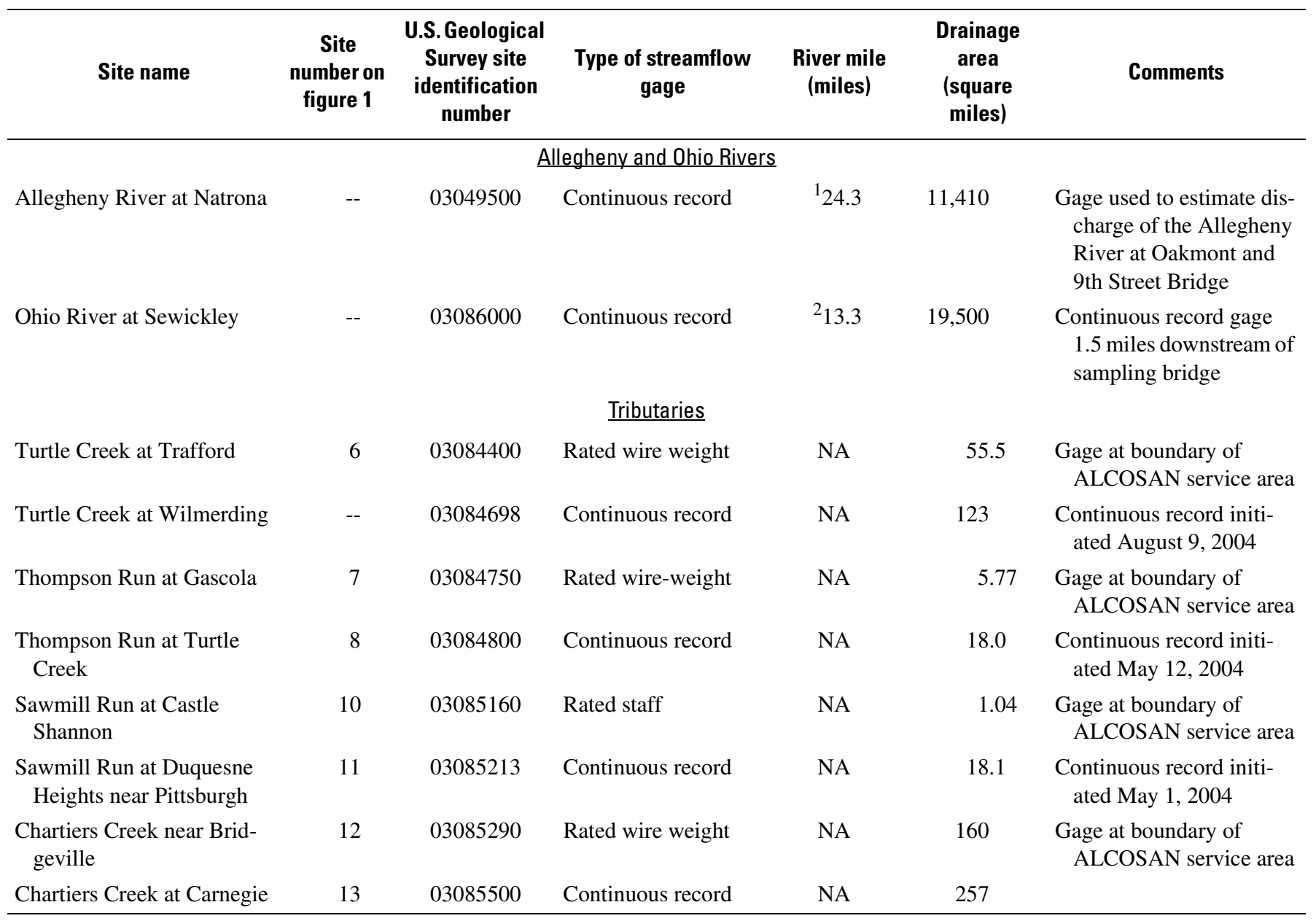

${ }^{1}$ River miles are measured from the site to the mouth of the Allegheny River.

${ }^{2}$ River miles are measured from the site to the confluence of the Allegheny and Monongahela Rivers.

\section{Statistical Methods}

Spearman's rho statistical test was used as a general screening tool to determine if correlations were present among indicator bacteria concentrations and field characteristics of water temperature, $\mathrm{pH}$, specific conductance, dissolved oxygen, and turbidity. To compute Spearman's correlation coefficients on the data set for this study that included multiple detection limits for $E$. coli concentrations, the data were censored at the higher detection limit $(<10 \mathrm{col} / 100 \mathrm{~mL})$. After censoring to a common detection limit, Spearman's rho correlation coefficient was computed on the ranks (Helsel, 2005). Correlations at the 95-percent confidence interval ( $\mathrm{p}$-value less than or equal to 0.05 ), as determined by Spearman's rho, were considered statistically significant.

The Wilcoxon rank-sum test was used to compare two independent groups of data. The test determines differences in the sum of the ranks between the two groups (for example,
E. coli concentrations in right-bank samples on the Monongahela River at Pittsburgh compared to E. coli concentrations in composites samples at the same location). The level of confidence was set at 90 percent with probabilities of 0.10 or less indicating statistical differences between the two groups of data.

\section{Quality Control}

Quality-control measures were observed and implemented to ensure data quality met project objectives, and included the collection of field duplicate samples and blank samples. Field duplicate samples were collected and field blank samples were prepared for fecal-indicator bacteria at a rate of about 7 percent and 2 percent, respectively, of the total number of samples collected and were processed by the ACHD Laboratory. 
Field duplicate samples for fecal-indicator bacteria were processed and analyzed to test analytical and sampling variability. Duplicate samples were collected at the Three Rivers sites upstream of the Ohio River at Sewickley (excluding the Ohio River at Sewickley site). In 2004, duplicate samples were collected at Turtle Creek at East Pittsburgh (tributary site to the Monongahela River) because of the large drainage-area size and abundance of sewage outfalls in the Turtle Creek watershed. The results generally were similar between all duplicate sample pairs. Analytical results of duplicate samples agreed within 20 percent for 70 out of 75 sample pairs analyzed between 2001 and 2005 (65 sample pairs agreed within 10 percent). Sample pair results generally showed agreement in when fecal-indicator bacteria concentrations would be above or below the standard (72 of 75 sample pairs); three of 75 sample pairs did not agree-one sample had bacteria concentrations below standards or criteria and the other sample had bacteria concentrations above standards or criteria. This disagreement in sample pair results may have been because of incomplete mixing of the sample volumes. Even with vigorous shaking of the samples, complete homogeneous mixing of the sample may be difficult because of instantaneous settling of sediment/bacteria mixtures and clumping of bacteria to suspended organic substances.

Field blanks were prepared and analyzed to test the efficiency of sterilization of the bacteria sample bottles. Three types of sterilized bottles were routinely used in the analysis of fecal-indicator bacteria. During EDI sampling at the Three Rivers sites, 3-L sterilized bottles were used and a well-mixed sample was poured from the $3-\mathrm{L}$ bottle to a sterilized $250-\mathrm{mL}$ polyethylene bottle (the size used for samples for bacteriological analyses). During EWI sampling at the tributary sites, 1-L sterilized bottles were used following the same methodology as for the 3-L bottles. Efficiency of sterilization was tested separately for the 3-L bottles, $1-\mathrm{L}$ bottles, and the $250-\mathrm{mL}$ bottles. A certified sterile buffered water solution from the USGS Ocala Laboratory (Ocala, Fla.) was added to the 3-L bottle or 1-L bottle in the field and was sent to the ACHD laboratory for analysis of fecal coliform, E. coli, and enterococci. No fecal bacteria were detected in the repeated monthly trials of this procedure; this indicated the sterilization procedures for the 3-L and 1-L bottles were effective. A similar procedure was followed by pouring certified sterile buffered water into the sterilized $250-\mathrm{mL}$ bottle in the field and sending the sample to the ACHD laboratory for the analysis of fecal-indicator bacteria. No fecal bacteria were detected in the repeated trials of this procedure; this indicated the sterilization procedures for the $250-\mathrm{mL}$ bottles were effective.

Additional quality-control measures in the laboratory included the processing of filter blanks and procedure blanks. Filter blanks were processed to test the efficiency of the sterilization of the laboratory equipment and supplies before filtration of the environmental samples. Procedure blanks were run after filtration of the environmental samples to ensure proper rinsing techniques were being used such that there was no carryover between samples. These tests were run on a routine basis and indicated no problems with sterilization and filtration procedures.

\section{Occurrence and Distribution of Fecal- Indicator Bacteria}

The samples collected in the Three Rivers and selected tributaries frequently exceeded established recreational standards and criteria for bacteria (table 1). A total of 1,027 water samples were collected from July 2001 to August 2005 for this study (U.S. Geological Survey, 2006). Fecal coliform bacteria were detected in 1,013 of 1,027 samples (98.6 percent). Concentrations of fecal coliform exceeded the Pennsylvania recreational water-quality standard of $200 \mathrm{col} / 100 \mathrm{~mL}$ in $650 \mathrm{of}$ 1,027 samples (63.3 percent) in the 5-year sampling period. E. coli bacteria were detected in 1,003 of 1,018 samples (98.5 percent). The USEPA recreational water-quality criterion of $235 \mathrm{col} / 100 \mathrm{~mL}$ was exceeded in 537 samples ( 52.8 percent) in the 5-year sampling period. Enterococci bacteria were detected in 888 of 1,013 samples ( 87.7 percent). The USEPA recreational water-quality criterion of $61 \mathrm{col} / 100 \mathrm{~mL}$ was exceeded in 475 samples ( 46.9 percent) in the 5 -year sampling period.

\section{Field Characteristics and Bacteria Concentrations and Distributions}

Data from selected field characteristics and fecal-indicator bacteria were assessed using general statistics as a first step in analyzing the occurrence and distribution of bacteria among sites on the Three Rivers and selected tributaries. Summary statistics grouped by the five Three Rivers sites that include median, minimum, and maximum measurements of streamflow, temperature, turbidity, and fecal-indicator bacteria as well as the percentage of samples that exceeded established waterquality standards or criteria are shown in table 4 . Median streamflow measurements were similar among sites (ranged from 4,930 to $6,620 \mathrm{ft}^{3} / \mathrm{s}$ ), except for the Ohio River at Sewickley that had the highest median of $11,600 \mathrm{ft}^{3} / \mathrm{s}$. The Ohio River at Sewickley also was where the highest streamflow $\left(40,800 \mathrm{ft}^{3} / \mathrm{s}\right)$ was measured following a storm on September 23, 2003. Water temperature was similar among sites; median temperatures ranged from 22.8 to $25.7^{\circ} \mathrm{C}$. Median turbidity measurements ranged from 6.4 to 12 NTU. The highest turbidity of 120 NTU was measured in a sample collected at the Allegheny River at 9th Street Bridge following a storm on August 8, 2001.

Fecal coliform, E. coli, and enterococci concentrations ranged from less than the detection limit (nondetects) to 50,000, 39,000 , and 3,400 col/100 $\mathrm{mL}$, respectively. The maximum bacteria concentrations at the five Three Rivers sites were detected in water samples collected at the Monongahela River at Pittsburgh - the fecal coliform and E. coli maximum concentrations were measured following a storm on August 28, 2001; the enterococci maximum concentration was measured following a storm June 23, 2004. The percentage of samples at the Three Rivers sites that exceeded water-quality standards or criteria ranged from 25 to 73 percent for fecal coliform (Pennsyl- 
Table 4. Summary statistics for streamflow, temperature, turbidity, and concentrations of fecal-indicator bacteria for the five sampling sites on the Three Rivers, Allegheny County, Pennsylvania, 2001-2005.

[n, number of samples; WQS, 30-day geometric mean water-quality standards or criteria; NTU, Nephelometric Turbidity Units; n/a, not applicable; <, less than]

\begin{tabular}{|c|c|c|c|c|c|c|}
\hline Sample statistics & $\begin{array}{c}\text { Streamflow, } \\
\text { in cubic feet } \\
\text { per second }\end{array}$ & $\begin{array}{c}\text { Temperature, } \\
\text { in degrees } \\
\text { Celsius }\end{array}$ & $\begin{array}{c}\text { Turbidity, } \\
\text { in NTU }\end{array}$ & $\begin{array}{c}\text { Fecal } \\
\text { coliform, in } \\
\text { colonies per } \\
100 \text { milliliters }{ }^{1}\end{array}$ & $\begin{array}{c}\text { Escherichia } \\
\text { coli, } \\
\text { in colonies } \\
\text { per } 100 \\
\text { milliliters } 2\end{array}$ & $\begin{array}{c}\text { Enterococci, } \\
\text { in colonies } \\
\text { per } 100 \\
\text { milliliters }\end{array}$ \\
\hline \multicolumn{7}{|c|}{ Allegheny River at Oakmont } \\
\hline Minimum & 3,080 & 14.5 & 1.0 & $<10$ & $<10$ & $<10$ \\
\hline Maximum & 26,300 & 33.0 & 95 & 5,750 & 1,100 & 690 \\
\hline $\mathrm{n}$ & 136 & 106 & 133 & 135 & 136 & 136 \\
\hline Percentage of samples exceeding WQS & $\mathrm{n} / \mathrm{a}$ & $\mathrm{n} / \mathrm{a}$ & $\mathrm{n} / \mathrm{a}$ & 25 & 13 & 21 \\
\hline \multicolumn{7}{|c|}{$\underline{\text { Allegheny River at 9th Street Bridge }}$} \\
\hline $\mathrm{n}$ & 143 & 141 & 142 & 143 & 141 & 143 \\
\hline Percentage of samples exceeding WQS & $\mathrm{n} / \mathrm{a}$ & $\mathrm{n} / \mathrm{a}$ & $\mathrm{n} / \mathrm{a}$ & 57 & 43 & 29 \\
\hline \multicolumn{7}{|c|}{$\underline{\text { Monongahela River at McKeesport }}$} \\
\hline Minimum & 3,100 & 15.3 & 2.8 & $<10$ & $<10$ & $<10$ \\
\hline Median & 6,620 & 22.8 & 11 & 135 & 123 & 15 \\
\hline Maximum & 22,600 & 29.6 & 74 & 690 & 910 & 320 \\
\hline $\mathrm{n}$ & 45 & 51 & 52 & 54 & 54 & 54 \\
\hline Percentage of samples exceeding WQS & $\mathrm{n} / \mathrm{a}$ & $\mathrm{n} / \mathrm{a}$ & $\mathrm{n} / \mathrm{a}$ & 33 & 24 & 18 \\
\hline \multicolumn{7}{|c|}{ Monongahela River at Pittsburgh } \\
\hline \multicolumn{7}{|c|}{$\underline{\text { Ohio River at Sewickley }}$} \\
\hline Minimum & 4,090 & 11.3 & 2.0 & $<10$ & $<10$ & $<10$ \\
\hline Median & 11,600 & 23.0 & 12 & 170 & 130 & 25 \\
\hline Maximum & 40,800 & 32.0 & 60 & 31,000 & 5,100 & 2,000 \\
\hline $\mathrm{n}$ & 135 & 108 & 134 & 135 & 134 & 135 \\
\hline Percentage of samples exceeding WQS & $\mathrm{n} / \mathrm{a}$ & $\mathrm{n} / \mathrm{a}$ & $\mathrm{n} / \mathrm{a}$ & 45 & 40 & 27 \\
\hline
\end{tabular}

${ }^{1}$ May 1 to September 30 water-quality standard is 200 colonies per 100 milliliters for fecal coliform (Pennsylvania Code, 25 PaCode $\left.§ 93.7\right)$.

${ }^{2}$ Year-round water-quality standard is 235 and 61 colonies per 100 milliliters for Escherichia coli and enterococci, respectively (U.S. Environmental Protection Agency, 1986).

vania water-quality standard of $200 \mathrm{col} / 100 \mathrm{~mL}$ ), 13 to 52 percent for $E$. coli (USEPA water-quality criterion of $235 \mathrm{col} / 100 \mathrm{~mL}$ ), and 18 to 34 percent for enterococci (USEPA water-quality criterion of $61 \mathrm{col} / 100 \mathrm{~mL}$ ). Allegheny River at Oakmont (the furthest upstream Three Rivers site) generally had the lowest percentages of samples that exceeded bacteria standards or criteria; Monongahela River at Pittsburgh (the furthest downstream site prior to the confluence of the Allegheny and the Monongahela Rivers with the Ohio River) had the greatest percentages of samples that exceeded standards or criteria. 
Flow augmentation associated with upstream reservoirs operated and maintained by the U.S. Army Corp of Engineers along the Allegheny River may provide some degree of dilution for fecal loads discharged to the Allegheny River. Depending on the time of year, these reservoirs can provide as much as 25 percent of the flow reported at the streamflow-gaging station at Allegheny River at Natrona, 11.6 mi upstream of Allegheny River at Oakmont.

Data from selected field characteristics and fecal-indicator bacteria also were compiled for eight tributary sites. Summary statistics grouped by tributary site for select field characteristics and fecal-indicator bacteria as well as the percentage of samples that exceed established water-quality standards or criteria are shown in table 5.

Median streamflow varied widely among tributary sites and ranged from 1 to $390 \mathrm{ft}^{3} / \mathrm{s}$. Sawmill Run at Castle Shannon had the lowest streamflows (from 0.00 to $44.0 \mathrm{ft}^{3} / \mathrm{s}$ ); the two sites on Chartiers Creek, Chartiers Creek near Bridgeville and Chartiers Creek at Carnegie, had the highest streamflows - $13,500 \mathrm{ft}^{3} / \mathrm{s}$ and $11,600 \mathrm{ft}^{3} / \mathrm{s}$, respectively. The maximum streamflows measured at both sites on Chartiers Creek were on September 17, 2004, following a storm from the remnants of Hurricane Ivan. Water temperature was similar among sites; median temperatures ranged from 15.9 to $17.9^{\circ} \mathrm{C}$ in seven of the eight tributary sites. Sawmill Run at Duquesne Heights near Pittsburgh had the highest median temperature of $20.0^{\circ} \mathrm{C}$. Median turbidity measurements ranged from 2.2 to 70 NTU. As with streamflow, Sawmill Run at Castle Shannon had the lowest turbidity measurements, ranging from 0.30 to $75.0 \mathrm{NTU}$. The highest turbidity measurement of 2,000 NTU was in a sample collected at Turtle Creek at East Pittsburgh following a storm from the remnants of Hurricane Ivan on September 17, 2004.

Fecal coliform, E. coli, and enterococci concentrations ranged from less than the detection limit (nondetects) to $410,000,510,000$, and 180,000 col/100 mL, respectively. The maximum fecal-indicator bacteria concentrations were at Sawmill Run at Duquesne Heights on September 17, 2004, following a storm from the remnants of Hurricane Ivan. The percentage of samples from the tributary sites that exceeded waterquality standards or criteria ranged from 29 to 100 percent for fecal coliform (Pennsylvania water-quality standard of $200 \mathrm{col} / 100 \mathrm{~mL}$ ), 30 to 100 percent for $E$. coli (USEPA waterquality criterion of $235 \mathrm{col} / 100 \mathrm{~mL}$ ), and 42 to 100 percent for enterococci (USEPA water-quality criterion of $61 \mathrm{col} / 100 \mathrm{~mL}$ ). Thompson Run at Gascola (the upstream site on the Thompson Run tributary) had the lowest percentages of samples that exceeded water-quality standards or criteria. Turtle Creek at East Pittsburgh (the downstream site on the Turtle Creek tributary), Sawmill Run at Castle Shannon (the upstream site on the Sawmill Run tributary), and Sawmill Run at Duquesne Heights near Pittsburgh (the downstream site on the Sawmill Run tributary) had samples that exceeded water-quality standards or criteria 94 percent of the time or more.

Statistically significant correlations were found between fecal-indicator bacteria (fecal coliform, E. coli, and enterococci bacteria) and selected field characteristics of water samples col- lected at the Three Rivers sites (table 6A) and at the tributary sites (table 6B). The strongest correlations generally were those between fecal-indicator bacteria and streamflow, specific conductance, and turbidity. For example, significant correlations existed between fecal coliform, E. coli, and enterococci with respect to turbidity at the Ohio River at Sewickley with Spearman's rho correlation coefficients of $0.653,0.583$, and 0.592 , respectively. The correlations at the Ohio River at Sewickley between fecal-indicator bacteria and turbidity were the strongest in the Three Rivers sites. However, the correlations generally were stronger for data collected at the tributary sites compared to data collected at the Three Rivers sites. For example, significant correlations existed between fecal coliform, E. coli, and enterococci at Chartiers Creek near Bridgeville with respect to specific conductance with Spearman's rho correlation coefficients of $-0.811,-0.857$, and -0.813 , respectively. The inverse correlation (negative correlation) between bacteria and specific conductance seems reasonable. Specific conductance of water is affected by the dissolution of bedrock and soil and tends to be highest during dry-weather events when the relative contributions to streamflow from ground water are highest. Conversely, during wet-weather events while bacteria concentrations tend to be high, specific conductance tends to be low in the study area (flushing-out effect on specific conductance by direct runoff). Strong correlations also were observed between fecal coliform and E. coli and streamflow at Sawmill Run at Duquesne Heights with Spearman's rho correlation coefficients of 0.804 and 0.812 , respectively. In general, correlations between fecal-indicator bacteria and streamflow tended to be present and were stronger further downstream, possibly a result of high bacteria inputs/outfalls in the reach between the upstream and downstream sites. Weaker correlations existed between fecal-indicator bacteria and other variables at all sites as indicated by smaller values of Spearman's rho.

\section{Weather Effects}

The effect of weather on bacteria concentrations was evaluated among Three Rivers sites and tributary sites. Comparisons were made among composite samples collected during dry- and wet-weather conditions to determine if differences existed; bacteria concentrations during dry- and wet-weather conditions were compared to recreational standards and criteria. The effects of extreme wet-weather conditions also were evaluated by comparing bacteria concentrations from samples collected at tributary sites before and after a major storm (a storm from the remnants of Hurricane Frances). Finally, the effects of weather on bacteria concentrations in samples collected from each of the three major subbasins (Allegheny, Monongahela, and Ohio subbasins) were evaluated separately due to the large numbers of sewer outfalls in each subbasin. 
Table 5. Summary statistics for streamflow, temperature, turbidity, and concentrations of fecal-indicator bacteria for the eight sampling sites on Chartiers Creek, Sawmill Run, Thompson Run, and Turtle Creek, Allegheny County, Pennsylvania, 2004-2005.

[n, number of samples; WQS, 30-day geometric mean water-quality standards or criteria; NTU, Nephelometric Turbidity Units; n/a, not applicable; <, less than]

\begin{tabular}{|c|c|c|c|c|c|c|}
\hline Sample statistics & $\begin{array}{c}\text { Streamflow, } \\
\text { in cubic feet } \\
\text { per second }\end{array}$ & $\begin{array}{c}\text { Temperature, } \\
\text { in degrees } \\
\text { Celsius }\end{array}$ & $\begin{array}{l}\text { Turbidity, } \\
\text { in NTU }\end{array}$ & $\begin{array}{c}\text { Fecal } \\
\text { coliform, } \\
\text { in colonies } \\
\text { per } 100 \\
\text { milliliters }{ }^{1}\end{array}$ & $\begin{array}{c}\text { Escherichia } \\
\text { coli, } \\
\text { in colonies } \\
\text { per } 100 \\
\text { milliliters }\end{array}$ & $\begin{array}{c}\text { Enterococci } \\
\text { in colonies } \\
\text { per } 100 \\
\text { milliliters }\end{array}$ \\
\hline \multicolumn{7}{|c|}{$\underline{\text { Turtle Creek at Trafford }}$} \\
\hline Minimum & 9.00 & 3.5 & 2.5 & 40 & 10 & $<10$ \\
\hline Maximum & 960 & 23.5 & 340 & 15,000 & 13,000 & 11,000 \\
\hline $\mathrm{n}$ & 21 & 23 & 23 & 24 & 22 & 24 \\
\hline Percentage of samples exceeding WQS & $\mathrm{n} / \mathrm{a}$ & $\mathrm{n} / \mathrm{a}$ & $\mathrm{n} / \mathrm{a}$ & 71 & 68 & 75 \\
\hline \multicolumn{7}{|c|}{ Thompson Run at Gascola } \\
\hline $\mathrm{n}$ & 21 & 23 & 24 & 24 & 23 & 24 \\
\hline Percentage of samples exceeding WQS & $\mathrm{n} / \mathrm{a}$ & $\mathrm{n} / \mathrm{a}$ & $\mathrm{n} / \mathrm{a}$ & 29 & 30 & 42 \\
\hline \multicolumn{7}{|c|}{$\underline{\text { Thompson Run at Turtle Creek }}$} \\
\hline Minimum & 8.00 & 4.5 & 1.8 & 50 & 60 & $<10$ \\
\hline Median & 16.0 & 16.3 & 10 & 2,200 & 1,900 & 340 \\
\hline Maximum & 665 & 22.0 & 900 & 43,000 & 49,000 & 9,100 \\
\hline $\mathrm{n}$ & 22 & 23 & 25 & 25 & 23 & 25 \\
\hline Percentage of samples exceeding WQS & $\mathrm{n} / \mathrm{a}$ & $\mathrm{n} / \mathrm{a}$ & $\mathrm{n} / \mathrm{a}$ & 88 & 91 & 88 \\
\hline \multicolumn{7}{|c|}{$\underline{\text { Turtle Creek at East Pittsburgh }}$} \\
\hline \multicolumn{7}{|c|}{$\underline{\text { Sawmill Run at Castle Shannon }}$} \\
\hline Minimum & .00 & 5.6 & .3 & 200 & 10 & $<10$ \\
\hline Median & 1.00 & 16.4 & 2.2 & 1,600 & 1,700 & 640 \\
\hline Maximum & 44.0 & 25.5 & 75 & 110,000 & 28,000 & 21,000 \\
\hline $\mathrm{n}$ & 27 & 33 & 32 & 33 & 33 & 33 \\
\hline Percentage of samples exceeding WQS & $\mathrm{n} / \mathrm{a}$ & $\mathrm{n} / \mathrm{a}$ & $\mathrm{n} / \mathrm{a}$ & 97 & 94 & 94 \\
\hline \multicolumn{7}{|c|}{ Sawmill Run at Duquesne Heights near Pittsburgh } \\
\hline Minimum & 4.00 & 4.5 & .6 & 220 & 70 & 70 \\
\hline Median & 20.0 & 20.0 & 23 & 17,000 & 10,500 & 2,200 \\
\hline Maximum & 1,530 & 27.0 & 600 & 410,000 & 510,000 & 180,000 \\
\hline $\mathrm{n}$ & 48 & 49 & 48 & 52 & 52 & 37 \\
\hline Percentage of samples exceeding WQS & $\mathrm{n} / \mathrm{a}$ & $\mathrm{n} / \mathrm{a}$ & $\mathrm{n} / \mathrm{a}$ & 100 & 96 & 100 \\
\hline
\end{tabular}


12 Fecal-Indicator Bacteria in the Allegheny, Monongahela, and Ohio Rivers and Selected Tributaries, 2001-2005

Table 5. Summary statistics for streamflow, temperature, turbidity, and concentrations of fecal-indicator bacteria for the eight sampling sites on Chartiers Creek, Sawmill Run, Thompson Run, and Turtle Creek, Allegheny County, Pennsylvania, 2004-2005. - Continued

[n, number of samples; WQS, 30-day geometric mean water-quality standards or criteria; NTU, Nephelometric Turbidity Units; n/a, not applicable; <, less than]

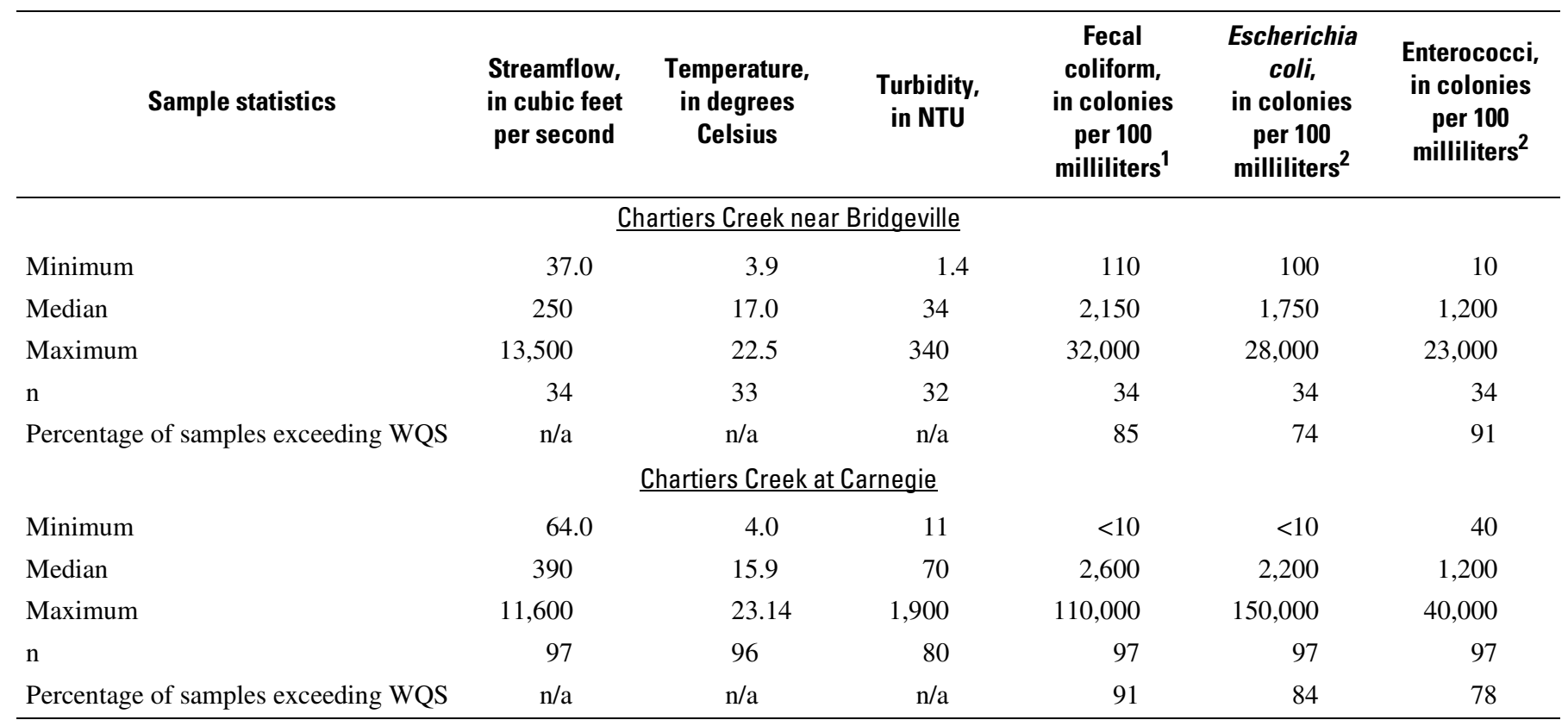

\footnotetext{
${ }^{1}$ May 1 to September 30 water-quality standard is 200 colonies per 100 milliliters for fecal coliform (Pennsylvania Code, 25 PaCode $\S 93.7$ ).

${ }^{2}$ Year round water-quality criteria is 235 and 61 colonies per 100 milliliters for Escherichia coli and enterococci, respectively (U.S. Environmental Protection Agency, 1986).
} 
Table 6. Summary of Spearman's rho correlations between fecal-indic ator bacteria concentrations in water and field characteristics at the (A) Three Rivers sites and (B) select tributary sites near Pittsburgh, Pennsylvania, 2001-2005.

[n, number of samples; rho, Spearman's rho; p-value, probability; <, less than; bold type indicates statistically significant correlation at the 95-percent confidence level (p-value 0.05 or less)]

\begin{tabular}{|c|c|c|c|c|c|c|c|}
\hline \multicolumn{8}{|l|}{ (A) Three Rivers sites } \\
\hline \multirow{2}{*}{ Variable } & \multirow{2}{*}{$\mathbf{n}$} & \multicolumn{2}{|c|}{ Fecal coliform } & \multicolumn{2}{|c|}{ Escherichia coli } & \multicolumn{2}{|c|}{ Enterococci } \\
\hline & & rho & $p$-value & rho & p-value & rho & p-value \\
\hline \multicolumn{8}{|c|}{ Allegheny River at Oakmont } \\
\hline Streamflow & 136 & 0.356 & $<0.0001$ & 0.424 & $<0.0001$ & 0.309 & 0.0002 \\
\hline Water temperature & 106 & -.297 & .002 & -.339 & .0004 & -.082 & .402 \\
\hline $\mathrm{pH}$ & 132 & -.100 & .254 & -.036 & .679 & -.161 & .065 \\
\hline Specific conductance & 134 & -.064 & .458 & -.200 & .021 & -.102 & .242 \\
\hline Dissolved oxygen & 90 & .055 & .609 & -.051 & .634 & .081 & .450 \\
\hline Turbidity & 133 & .302 & .0004 & .538 & $<.0001$ & .268 & .002 \\
\hline \multicolumn{8}{|c|}{ Allegheny River at 9th Street Bridge } \\
\hline Streamflow & 143 & .205 & .014 & .271 & .001 & .373 & $<.0001$ \\
\hline Water temperature & 141 & .041 & .627 & -.025 & .771 & .030 & .722 \\
\hline $\mathrm{pH}$ & 139 & -.260 & .002 & -.263 & .002 & -.300 & .0003 \\
\hline Specific conductance & 142 & .098 & .245 & -.042 & .622 & -.115 & .171 \\
\hline Dissolved oxygen & 122 & -.145 & .110 & -.227 & .012 & -.327 & .0002 \\
\hline Turbidity & 142 & .158 & .060 & .169 & .045 & .182 & .030 \\
\hline \multicolumn{8}{|c|}{ Monongahela River at McKeesport } \\
\hline Streamflow & 45 & .392 & .008 & .408 & .005 & .528 & .0002 \\
\hline Water temperature & 51 & -.333 & .017 & -.397 & .004 & -.388 & .005 \\
\hline $\mathrm{pH}$ & 54 & -.322 & .018 & -.339 & .012 & -.378 & .005 \\
\hline Specific conductance & 54 & -.562 & $<.0001$ & -.556 & $<.0001$ & -.558 & $<.0001$ \\
\hline Dissolved oxygen & 54 & -.119 & .391 & -.024 & .864 & -.038 & .785 \\
\hline Turbidity & 52 & .419 & .002 & .466 & .0005 & .435 & .001 \\
\hline \multicolumn{8}{|c|}{ Monongahela River at Pittsburgh } \\
\hline Streamflow & 143 & .388 & $<.0001$ & .376 & $<.0001$ & .488 & $<.0001$ \\
\hline Water temperature & 139 & -.198 & .020 & -.356 & .001 & -.260 & .002 \\
\hline $\mathrm{pH}$ & 141 & -.317 & .0001 & -.242 & .004 & -.298 & .0003 \\
\hline Specific conductance & 141 & -.254 & .002 & -.199 & .018 & -.378 & $<.0001$ \\
\hline Dissolved oxygen & 120 & .037 & .684 & .038 & .680 & -.148 & .105 \\
\hline Turbidity & 140 & .302 & .0003 & .334 & .0001 & .425 & $<.0001$ \\
\hline \multicolumn{8}{|c|}{ Ohio River at Sewickley } \\
\hline Streamflow & 135 & .547 & $<.0001$ & .563 & $<.0001$ & .481 & $<.0001$ \\
\hline Water temperature & 108 & -.033 & .731 & -.118 & .225 & .164 & .090 \\
\hline $\mathrm{pH}$ & 133 & .226 & .009 & .165 & .058 & .197 & .023 \\
\hline Specific conductance & 133 & -.335 & $<.0001$ & -.320 & .002 & -.317 & .0002 \\
\hline Dissolved oxygen & 78 & .464 & $<.0001$ & .382 & .0006 & .318 & .004 \\
\hline Turbidity & 134 & .653 & $<.0001$ & .583 & $<.0001$ & .592 & $<.0001$ \\
\hline
\end{tabular}




\section{Fecal-Indicator Bacteria in the Allegheny, Monongahela, and Ohio Rivers and Selected Tributaries, 2001-2005}

Table 6. Summary of Spearman's rho correlations between fecal-indicator bacteria concentrations in water and field characteristics at the (A) Three Rivers sites and (B) select tributary sites near Pittsburgh, Pennsylvania, 2001-2005.—Continued

[n, number of samples; rho, Spearman's rho; p-value, probability; <, less than; bold type indicates statistically significant correlation at the 95-percent confidence level (p-value 0.05 or less)]

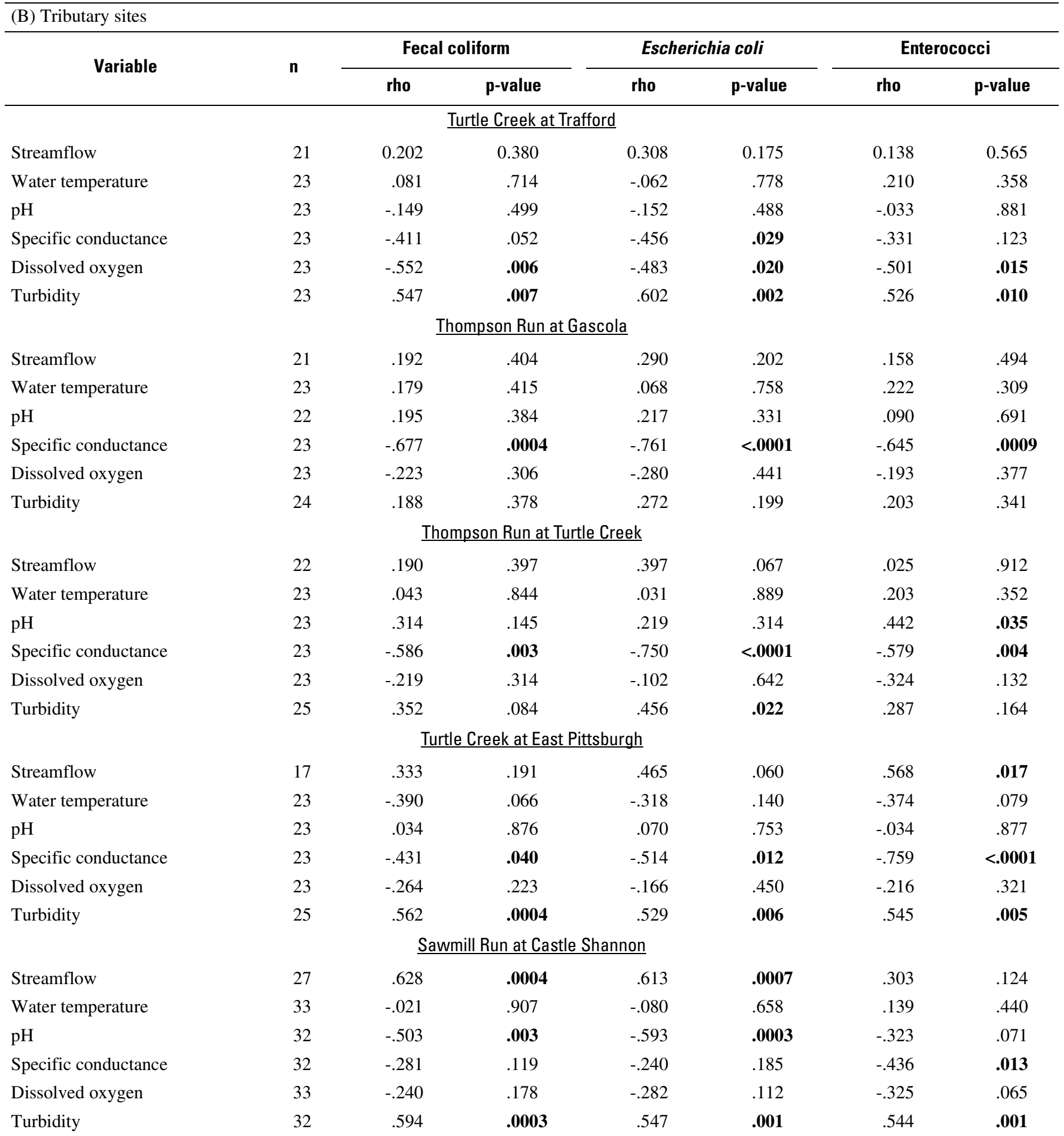


Table 6. Summary of Spearman's rho correlations between fecal-indicator bacteria concentrations in water and field characteristics at the (A) Three Rivers sites and (B) select tributary sites near Pittsburgh, Pennsylvania, 2001-2005.-Continued

[n, number of samples; rho, Spearman's rho; p-value, probability; <, less than; bold type indicates statistically significant correlation at the 95-percent confidence level (p-value 0.05 or less)]

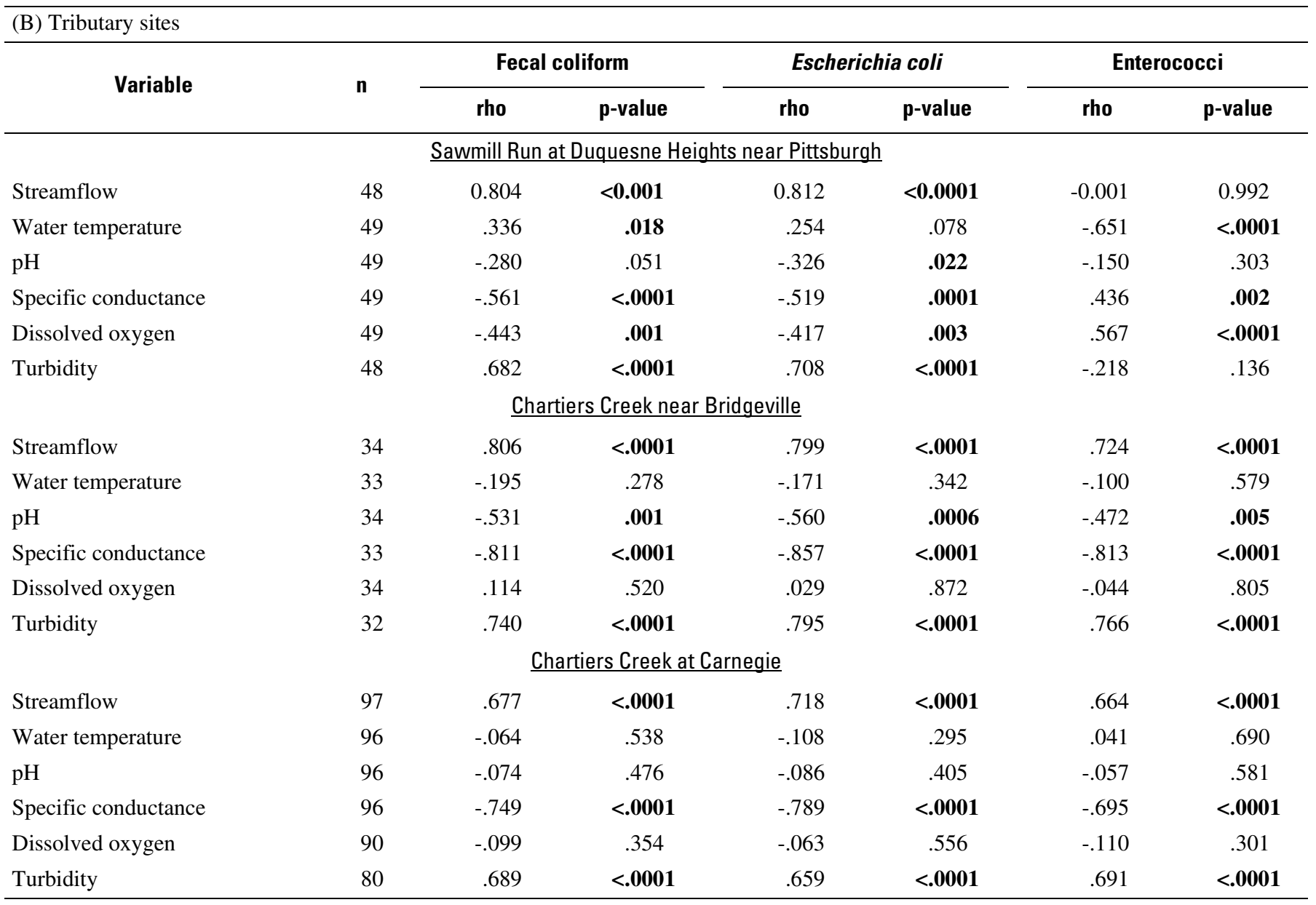


Comparisons were made between fecal-indicator bacteria and turbidity data from right-bank and composite samples, left-bank and composite samples, and right-bank and left-bank samples collected during dry- and wet-weather conditions at the upstream and downstream Three Rivers sampling locations within each of the three subbasins.

Differences in the bacteriological quality of waters among Three Rivers sites were observed by comparing composite samples collected during dry- and wet-weather conditions. As would be expected, samples collected during high flow and turbid water conditions following storms contained higher bacteria concentrations than samples collected during dry-weather conditions. In particular, two major storms - those resulting from remnants of Hurricanes Frances and Ivan in September 2004 - produced some of the highest measurements of select field characteristics and fecal-indicator bacteria. The range in bacteria concentrations grouped by Three Rivers sites during dry weather, wet weather day one, and wet weather day three are shown in figure 2 . The range in bacteria concentrations grouped by tributary site during dry weather, wet weather day one, and wet weather day two are shown in figure 3 .

Overall, about 35 percent of the composite samples collected at the Three Rivers sites had bacteria concentrations that exceeded recreational water-quality standards or criteria during dry- or wet-weather events. Median bacteria concentrations generally were higher in the wet-weather day-one composite samples compared to the dry-weather or wet-weather day-three composite samples at the Three Rivers sites (fig. 2); many median wet-weather day-one concentrations were higher than the water-quality standards or criteria. For example, all wetweather day-one concentrations observed for fecal coliform, E. coli, and enterococci in composite samples collected at Allegheny River at 9th Street Bridge, Monongahela River at Pittsburgh, and Ohio River at Sewickley exceeded standards and criteria. The median bacteria concentrations were highest in the wet-weather day-one composite samples collected at Monongahela River at Pittsburgh; median concentrations for fecal coliform, E. coli, and enterococci were 1,340, 1,130, and $130 \mathrm{col} / 100 \mathrm{~mL}$, respectively. Median bacteria concentrations in the dry-weather samples were below recreational water-quality standards and criteria for all fecal-indicator bacteria analyzed. Median bacteria concentrations in the wet-weather daythree composite samples tended to fall below the water-quality standards and criteria, in many cases near or below the median bacteria concentrations in the dry-weather composite samples. During dry- and wet-weather conditions, composite samples collected at Allegheny River at Oakmont and Monongahela River at McKeesport (Three Rivers sites furthest upstream) generally had lower bacteria concentrations than composite samples collected at Allegheny River at 9th Street Bridge, Monongahela River at Pittsburgh, or Ohio River at Sewickley.

Fecal-indicator bacteria concentrations in the dry- and wet-weather composite samples collected at the tributary sites (fig. 3) were more frequently above water-quality standards or criteria than composite samples collected at the Three Rivers sites. Many of the median bacteria concentrations in the dryweather composite samples and wet-weather composite sam- ples collected at the tributaries were above bacteria standards and criteria. Median bacteria concentrations in the wet-weather day-one composite samples collected at the tributaries generally were higher than median bacteria concentrations in the dryweather or wet-weather day-two composite samples. Fecal coliform and E. coli bacteria concentrations in the wet-weather composite samples were highest in the samples collected at Sawmill Run at Duquesne Heights; median concentrations in the wet-weather day-one composite samples were around $100,000 \mathrm{col} / 100 \mathrm{~mL}$. All wet-weather day-one bacteria concentrations from composite samples collected at the tributary sites exceeded recreational water-quality standards and criteria, with the exception of Thompson Run at Gascola that had concentrations from about half of the composite samples exceeding the standards and criteria. Median bacteria concentrations generally were higher during dry- and wet-weather conditions in the sites furthest downstream-Turtle Creek at East Pittsburgh and Sawmill Run and Chartiers Creek tributaries. The tributary site with the lowest median bacteria concentrations and the fewest cases of water-quality standards and criteria being exceeded during both dry- and wet-weather conditions was Thompson Run at Gascola. The upstream tributary sites on Turtle Creek, Thompson Run, and Chartiers Creek were the only sites with at least one median bacteria concentration in a dry-weather sample below water-quality standards or criteria.

The effects of extreme wet-weather conditions on streamflow and fecal-indicator bacteria concentrations also were evaluated by comparing samples collected at tributary sites before and after a major storm. On September 8, 2004, heavy rains that were the remnants of Hurricane Frances fell on western Pennsylvania. The long-term rain gage at Pittsburgh International Airport recorded 3.60 in. Rainfall totals were as high as 5.0 in. in parts of north-central and western areas of Allegheny County. The southeastern areas of Allegheny County, the area of Chartiers Creek in Washington County, and the part of Turtle Creek in Westmoreland County received in the range of 2-3 in. of rain.

Streamflow on tributary streams increased quickly on September 8, 2004, as a result of the rainfall and runoff during the day (table 7). The timing and magnitude of the highest mean daily streamflow varied from site to site as a function of precipitation amounts, runoff characteristics, and drainage-basin size upstream of the streamflow-gaging station. The highest mean daily streamflow was on September 8, 2004 (wet-weather day one), for Thompson Run at Turtle Creek and Sawmill Run at Duquesne Heights. These streams with drainage areas of 18.0 and $18.1 \mathrm{mi}^{2}$, respectively (table 1 ), are small urban watersheds with considerable amounts of impervious surfaces and steep stream gradients. The storm hydrographs showed rapid rises and rapid recessions from the storm runoff. Turtle Creek at Wilmerding, with a drainage area of $123 \mathrm{mi}^{2}$, and Chartiers Creek at Carnegie, with a drainage area of $257 \mathrm{mi}^{2}$, had the highest mean daily streamflow of the wet-weather event on September 9, 2004 (wet-weather day two). Stormwater runoff in the larger drainage area watersheds of Turtle Creek and 

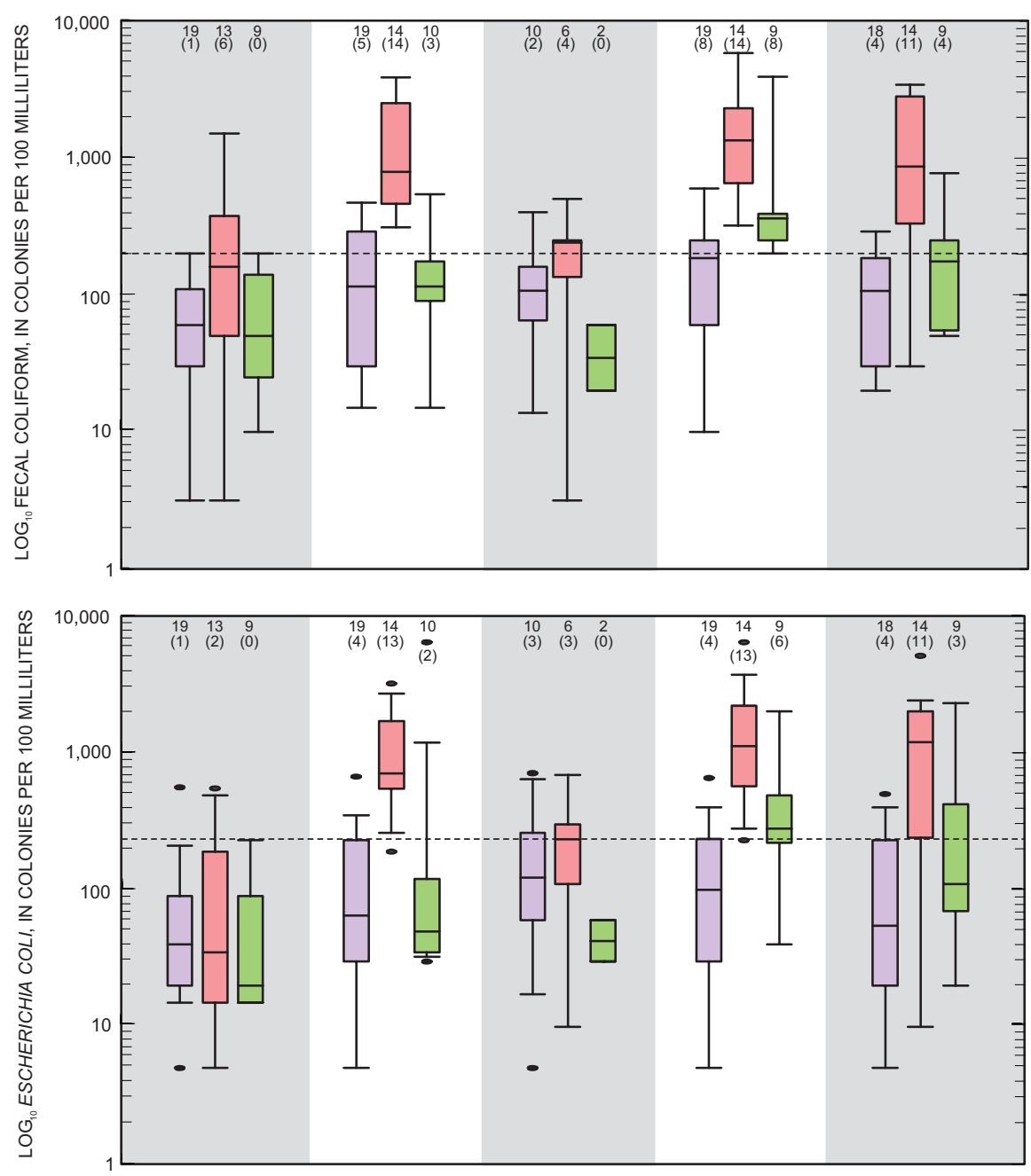

\section{EXPLANATION}

$\mathrm{N}$ Total number of samples

(N) Number of samples exceeding water-quality standards or criteria
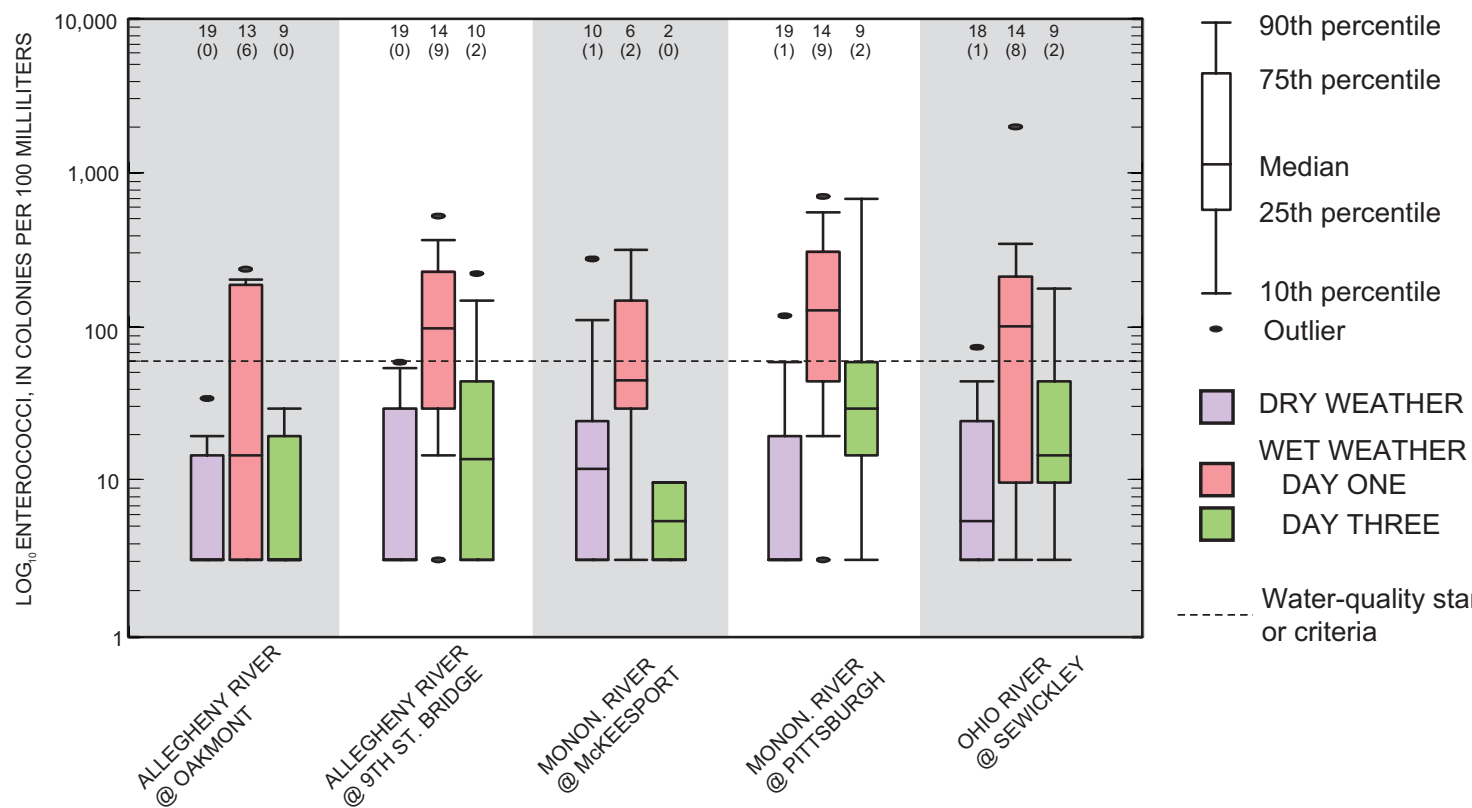

Water-quality standard or criteria

Figure 2. Comparison of fecal-indicator bacteria colonies in composite samples collected during dry and wet weather on the Allegheny, Monongahela, and Ohio Rivers near Pittsburgh, Allegheny County, Pennsylvania, 2001-2005. 

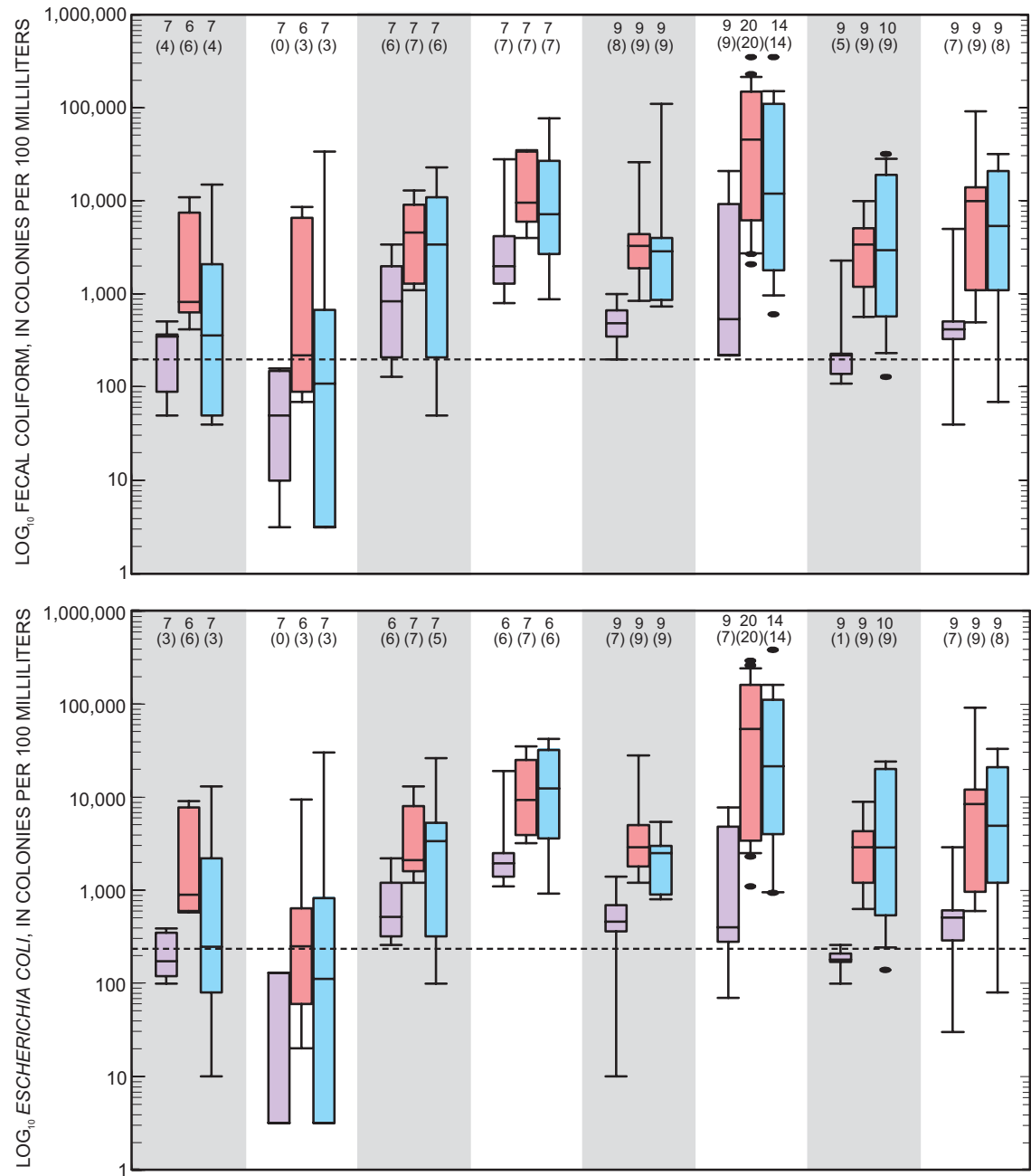

\section{EXPLANATION}

$\mathrm{N}$ Total number of samples

(N) Number of samples exceeding water-quality standards or criteria
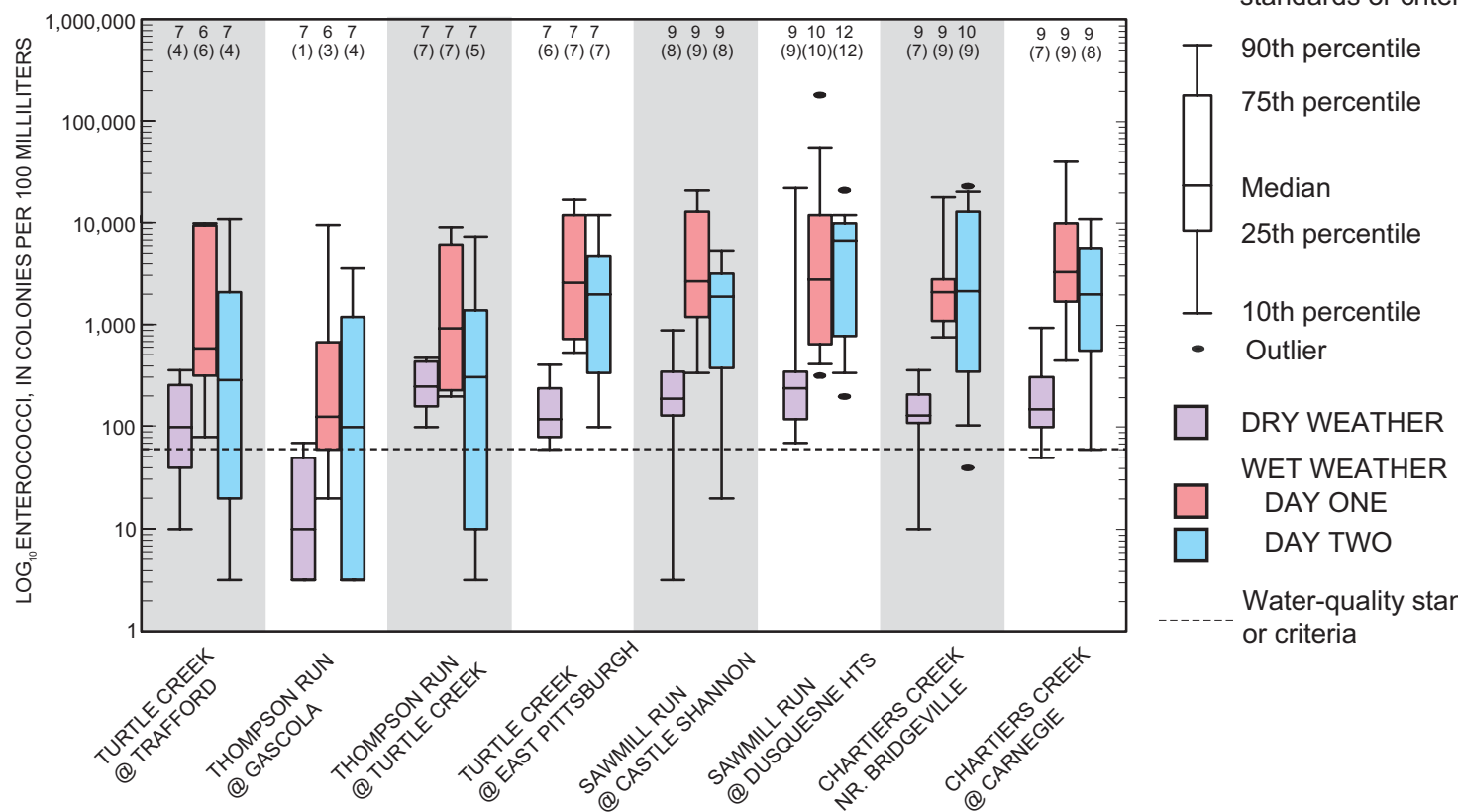

Water-quality standard or criteria

Figure 3. Fecal-indicator bacteria colonies in composite samples collected during dry and wet weather on Turtle Creek, Thompson Run, Sawmill Run, and Chartiers Creek, Allegheny County, Pennsylvania, 2004-2005. 
Table 7. Mean daily streamflows of tributary streams before and after the rainfall remnants of Hurricane Frances affected the streams of Allegheny County, Pennsylvania, September 7-10, 2004.

[ $\mathrm{ft}^{3} / \mathrm{s}$, cubic feet per second]

\begin{tabular}{|c|c|c|c|c|c|c|}
\hline Site name & $\begin{array}{l}\text { U.S. Geological } \\
\text { Survey site } \\
\text { identification } \\
\text { number }\end{array}$ & $\begin{array}{l}\text { Drainage area } \\
\text { (square miles) }\end{array}$ & $\begin{array}{c}\text { Dry weather } \\
9 / 7 / 04 \\
\text { Mean daily } \\
\text { discharge } \\
\left(\mathrm{ft}^{3} / \mathrm{s}\right)\end{array}$ & $\begin{array}{c}\text { Wet-weather } \\
\text { Day } 1 \\
9 / 8 / 04 \\
\text { Mean daily } \\
\text { discharge } \\
\left(\mathrm{ft}^{3} / \mathrm{s}\right)\end{array}$ & $\begin{array}{l}\text { Wet-weather } \\
\text { Day } 2 \\
9 / 9 / 04 \\
\text { Mean daily } \\
\text { discharge } \\
\left(\mathrm{ft}^{3} / \mathrm{s}\right)\end{array}$ & $\begin{array}{c}\text { Wet-weather } \\
\text { Day } 3 \\
\text { 9/10/04 } \\
\text { Mean daily } \\
\text { discharge } \\
\left(\mathrm{ft}^{3} / \mathbf{s}\right)\end{array}$ \\
\hline Thompson Run at Turtle Creek & 03084800 & 18.0 & 44 & 184 & 38 & 8 \\
\hline Turtle Creek at Wilmerding & 03084698 & 123 & 39 & 627 & 709 & 217 \\
\hline $\begin{array}{l}\text { Sawmill Run at Duquesne Heights } \\
\text { near Pittsburgh }\end{array}$ & 03085213 & 18.1 & 48 & 573 & 166 & 20 \\
\hline Chartiers Creek at Carnegie & 03085500 & 257 & 118 & 1,820 & 4,850 & 842 \\
\hline
\end{tabular}

Chartiers Creek had longer retention times in the watershed (about an extra day) when compared to stormwater runoff in the Thompson Run and Sawmill Run watersheds.

Concentrations of fecal-indicator bacteria for the eight sites on the tributary streams sampled during dry weather on September 7, 2004, are presented in figure 4. No precipitation was measured on September 5, 6, and during the day of sampling on September 7, 2004. On September 4, some scattered rain fell in Allegheny County, accumulating several tenths of an inch of precipitation, but streams did not show effects of runoff and continued to recede because of the dry weather. The concentrations of $E$. coli and fecal coliform were below the criteria and standard, respectively, on September 7, 2004, for samples collected at Thompson Run at Gascola and at Chartiers Creek near Bridgeville. All other concentrations of enterococci, $E$. coli, and fecal coliform were above the criteria and standard. The cause(s) of the elevated concentrations of enterococci, $E$. coli, and fecal coliform during dry weather are unknown, but possible sources included sewage discharging to tributary streams, waterfowl, malfunctioning sewage-treatment plants or overflows, leaking sewer lines, malfunctioning on-lot sewage systems, and agricultural runoff.

\section{Allegheny River Subbasins}

Significant differences in fecal-indicator bacteria concentrations and turbidity between cross-sectional sampling locations were observed during both dry- and wet-weather events at the Allegheny River sites. Wilcoxon rank-sum test results for fecal-indicator bacteria and turbidity data from right-bank and composite samples, left-bank and composite samples, and rightbank and left-bank samples collected during dry- and wetweather conditions are shown in table 8 . The Allegheny River sites had more significant differences ( 12 total -8 in wet weather, 4 in dry weather) than the Monongahela River sites or the Ohio River at Sewickley (table 8). For example, differences were observed for enterococci concentrations between rightbank and composite samples in both wet- and dry-weather sam- ples (p-values of 0.007 and 0.058 , respectively) collected at Allegheny River at Oakmont and in the dry-weather samples (p-value of 0.082) collected at Allegheny River at 9th Street Bridge. Another example of where differences were observed was for $E$. coli concentrations between right-bank and composite samples, left-bank and composite samples, and right-bank and left-bank samples during wet-weather conditions in samples collected at Allegheny River at Oakmont ( $\mathrm{p}$-values of $0.002,0.069$, and 0.069 , respectively). Bacteria concentrations typically were higher in the bank samples than in the composite samples during dry- and wet-weather events. This is an indication that bacteria from near-shore inputs tended to remain near the shore, regardless of weather conditions. No significant differences for wet- or dry-weather conditions were observed for fecal coliform or E. coli between sampling locations at Allegheny River at 9th Street Bridge or for turbidity between sampling locations at Allegheny River at Oakmont. No significant differences for dry-weather conditions were observed for fecal coliform, E. coli, or turbidity between sampling locations at Allegheny River at Oakmont (table 8).

A variety of point and nonpoint sources of fecal-indicator bacteria are probably responsible for the higher concentrations in wet-weather samples at Allegheny River at 9th Street Bridge compared to Allegheny River at Oakmont. Point sources of fecal-indicator bacteria included sewer outfalls directly on the banks of the Allegheny River and sewer outfalls on tributaries between the two sites (fig. 5). Nonpoint sources included sewage discharging to tributary streams, malfunctioning sewagetreatment plants or overflows, leaking sewer lines, malfunctioning on-lot sewage systems, agricultural runoff, and wildlife.

Sampling for fecal-indicator bacteria in tributary streams entering the Allegheny River between Oakmont and the 9th Street Bridge was not within the scope of this study; however, these tributary streams likely contributed to bacteria concentrations in the Allegheny River during dry- and wet-weather conditions. Data from a few samples collected from tributary streams in this reach of the Allegheny River were compiled by Reilly (2005). The compilation of data did not differentiate between wet- and dry-weather conditions with respect to the 


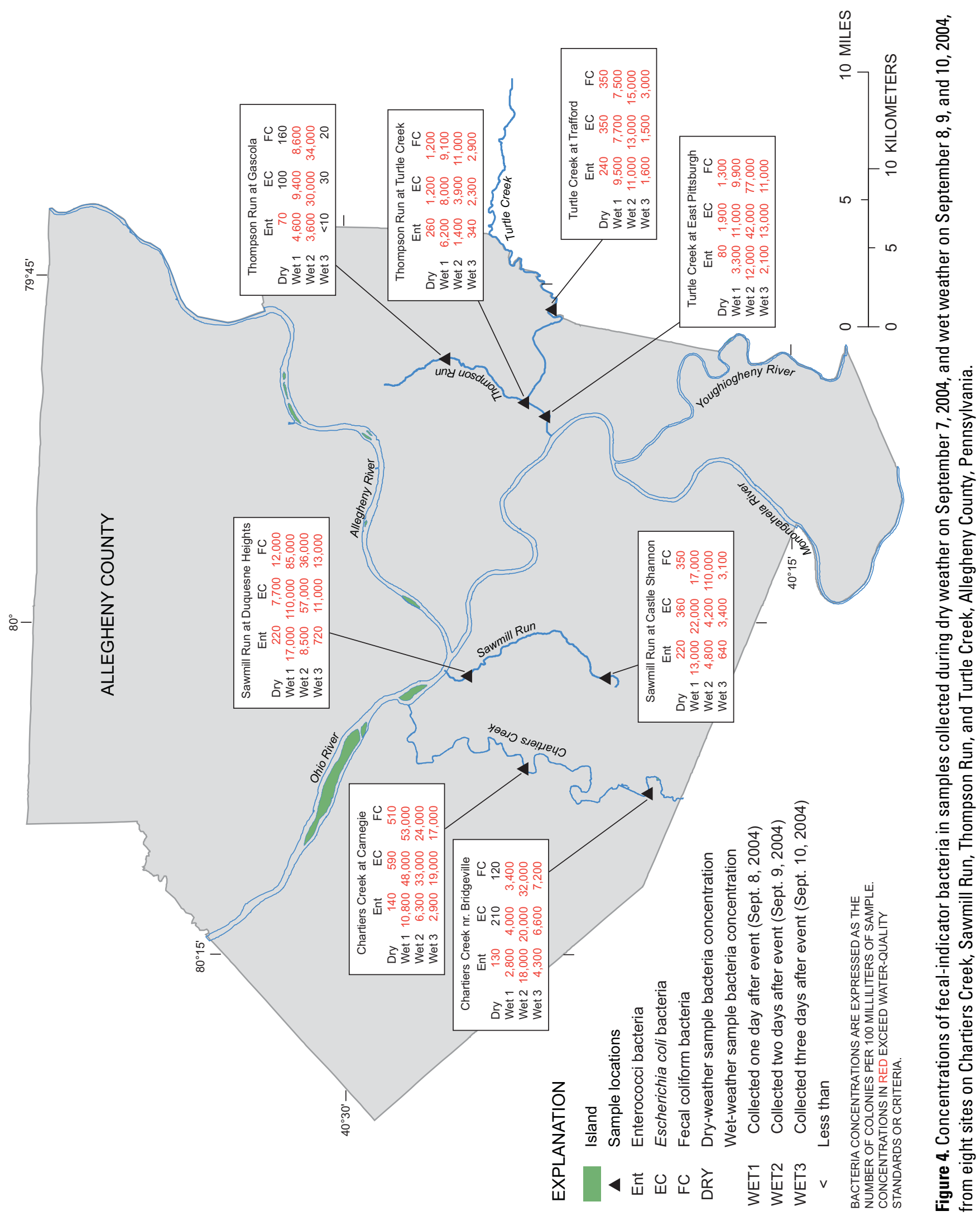


Table 8. Wilcoxon rank-sum comparison of sampling location differences in fecal-indicator bacteria and turbidity in dry- and wet-weather samples from five sites on the Allegheny, Monongahela, and Ohio Rivers, Allegheny County, Pennsylvania, 2001-2005.

[LB, left-bank sample; RB, right-bank sample; comp, composite sample; ns, not significant at the 90-percent confidence interval (p-value greater than 0.10)]

\begin{tabular}{|c|c|c|c|c|c|c|c|c|c|c|}
\hline \multirow{3}{*}{$\begin{array}{c}\text { Water-quality } \\
\text { parameter and } \\
\text { comparison tested }\end{array}$} & \multicolumn{4}{|c|}{ Allegheny River } & \multicolumn{4}{|c|}{ Monongahela River } & \multirow{2}{*}{\multicolumn{2}{|c|}{$\begin{array}{l}\text { Ohio River } \\
\text { Sewickley }\end{array}$}} \\
\hline & \multicolumn{2}{|c|}{ Oakmont } & \multicolumn{2}{|c|}{ 9th St. Bridge } & \multicolumn{2}{|c|}{ McKeesport } & \multicolumn{2}{|c|}{ Pittsburgh } & & \\
\hline & Wet & Dry & Wet & Dry & Wet & Dry & Wet & Dry & Wet & Dry \\
\hline \multicolumn{11}{|l|}{ Escherichia coli } \\
\hline RB - Comp & 0.002 & ns & $\mathrm{ns}$ & ns & $\mathrm{ns}$ & ns & ns & ns & $\mathrm{ns}$ & ns \\
\hline LB - Comp & .069 & ns & ns & ns & ns & $\mathrm{ns}$ & ns & ns & $\mathrm{ns}$ & ns \\
\hline $\mathrm{RB}-\mathrm{LB}$ & .069 & ns & ns & ns & $\mathrm{ns}$ & $\mathrm{ns}$ & $\mathrm{ns}$ & ns & $\mathrm{ns}$ & ns \\
\hline \multicolumn{11}{|l|}{ Enterococci } \\
\hline RB - Comp & .007 & .058 & $\mathrm{~ns}$ & .082 & $\mathrm{~ns}$ & $\mathrm{~ns}$ & ns & ns & $\mathrm{ns}$ & ns \\
\hline LB - Comp & $\mathrm{ns}$ & .079 & $\mathrm{~ns}$ & $\mathrm{~ns}$ & $\mathrm{~ns}$ & $\mathrm{~ns}$ & $\mathrm{~ns}$ & .019 & $\mathrm{~ns}$ & .016 \\
\hline RB - LB & $\mathrm{ns}$ & ns & $\mathrm{ns}$ & $\mathrm{ns}$ & $\mathrm{ns}$ & $\mathrm{ns}$ & $\mathrm{ns}$ & ns & $\mathrm{ns}$ & .002 \\
\hline \multicolumn{11}{|l|}{ Fecal coliform } \\
\hline RB - Comp & .024 & ns & $\mathrm{ns}$ & ns & $\mathrm{ns}$ & $\mathrm{ns}$ & $\mathrm{ns}$ & ns & $\mathrm{ns}$ & ns \\
\hline LB - Comp & .085 & ns & $\mathrm{ns}$ & ns & $\mathrm{ns}$ & $\mathrm{ns}$ & $\mathrm{ns}$ & ns & $\mathrm{ns}$ & $\mathrm{ns}$ \\
\hline RB - LB & $\mathrm{ns}$ & $\mathrm{ns}$ & $\mathrm{ns}$ & ns & ns & $\mathrm{ns}$ & $\mathrm{ns}$ & ns & $\mathrm{ns}$ & .090 \\
\hline \multicolumn{11}{|l|}{ Turbidity } \\
\hline RB - Comp & $\mathrm{ns}$ & ns & .047 & ns & $\mathrm{ns}$ & $\mathrm{ns}$ & $\mathrm{ns}$ & $\mathrm{ns}$ & $\mathrm{ns}$ & ns \\
\hline LB - Comp & $\mathrm{ns}$ & ns & .014 & .100 & ns & $\mathrm{ns}$ & .074 & ns & $\mathrm{ns}$ & $\mathrm{ns}$ \\
\hline $\mathrm{RB}-\mathrm{LB}$ & ns & ns & ns & ns & ns & $\mathrm{ns}$ & ns & ns & $\mathrm{ns}$ & ns \\
\hline
\end{tabular}

sampling. From the examination of the arithmetic mean and maximum data values for E. coli (Reilly, 2005, Appendix A, p. A9, A10), the following streams, all with drainage areas greater than $3.0 \mathrm{mi}^{2}$, contributed at least intermittently to concentrations of $E$. coli above the single-sample bathing-water criteria of $235 \mathrm{col} / 100 \mathrm{~mL}$ : 1) Plum Creek, 2) Sandy Creek, 3) Squaw Run, 4) Pine Creek, and 5) Girtys Run (fig. 5).

\section{Monongahela River Subbasins}

Few statistically significant differences were observed among bacteria and turbidity in samples collected from composite, right-bank, and left-bank locations on the Monongahela River sites during dry- or wet-weather events (table 8). Statistically significant differences (90-percent confidence level) were observed in enterococci bacteria concentrations during dryweather conditions and in turbidity measurements during wetweather conditions between left-bank and composite samples (p-values of 0.019 and 0.074 , respectively) in surface water collected at Monongahela River at Pittsburgh. Enterococci concentrations in the composite samples collected at Monongahela River at Pittsburgh were lower than enterococci concentrations in the left-bank samples during dry-weather conditions. The significant difference observed for enterococci may be an indication that bacteria from near-shore inputs tended to hug the left bank during dry weather. Turbidity measurements in the composite samples collected at Monongahela River at Pittsburgh were higher than turbidity measurements in left-bank samples during wet-weather conditions. This significant difference observed for turbidity may be an indication that, during wetweather conditions, there is a dilution effect near the shoreline as bacteria and sediment are being flushed further out into the stream channel. The same phenomena were not observed in all cases.

A variety of point and nonpoint sources of fecal-indicator bacteria likely were responsible for the higher concentrations at Monongahela River at Pittsburgh compared to Monongahela River at McKeesport during dry- and wet-weather events. Point sources of fecal-indicator bacteria included sewer outfalls directly on the banks of the Monongahela River and sewer outfalls on tributaries between the two sites (fig. 6). Sewer outfalls above the McKeesport site on the Youghiogheny River and sewer outfalls above the McKeesport site on the Monongahela River (fig. 6) probably contributed to fecal-indicator bacteria concentrations at the McKeesport site, especially during wet weather. The results of some dry-weather sampling and especially wet-weather sampling for Thompson Run at Turtle Creek and Turtle Creek at East Pittsburgh (fig. 3) indicate these streams contributed high concentrations of fecal-indicator bacteria to the Monongahela River.

Other tributaries not sampled as part of this study may contribute to high concentrations of fecal-indicator bacteria in the Monongahela River during dry- and wet-weather events. For example, the U.S. Army Corps of Engineers investigated the 


\section{EXPLANATION}

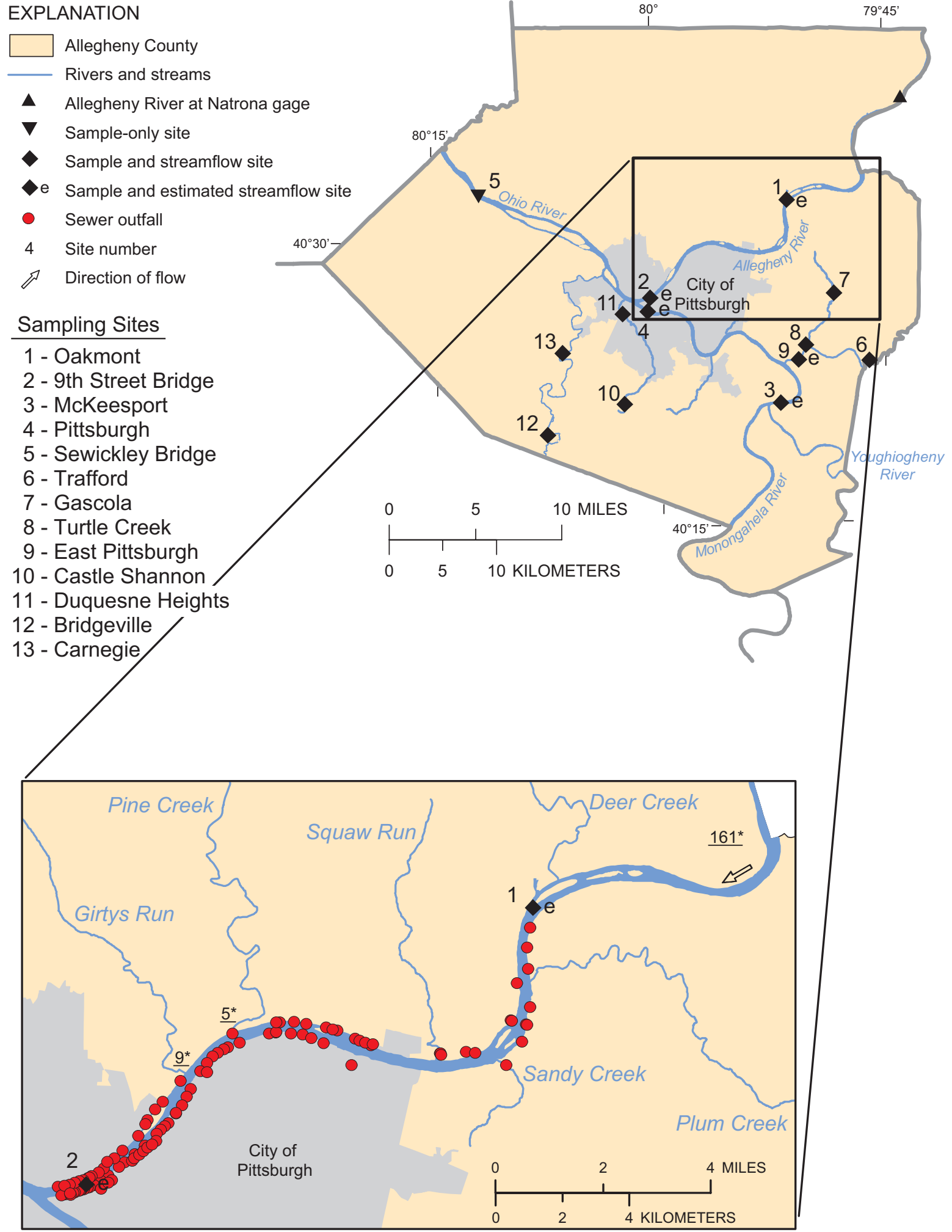

* Number of sewer outfalls upstream

Figure 5. Locations of data-collection sites and sewer outfalls on the Allegheny River, Allegheny County, Pennsylvania. 
contamination of Ninemile Run from sewage during dry and wet weather in 1999 at six sites (Koryak and Reilly, 2000). Ninemile Run is a 7.6- $\mathrm{mi}^{2}$ urban watershed that enters the Monongahela River at River mile 7.6 (fig. 6). Fecal coliform concentrations ranged from 125 to $1,051,200 \mathrm{col} / 100 \mathrm{~mL}$; E. coli ranged from 125 to 1,009,800 col/100 mL (Koryak and Reilly, 2000). From this information collected in 1999, Ninemile Run is a source of high fecal-indicator bacteria concentrations to the receiving waters of the Monongahela River. Ninemile Run is another watershed, in addition to Thompson Run and Turtle Creek, probably responsible for fecal-indicator bacteria concentrations being higher during wet weather at Monongahela River at Pittsburgh when compared to Monongahela River at McKeesport.

Nonpoint sources of fecal matter to the Monongahela River during dry- and wet-weather conditions included sewage discharging to tributary streams, malfunctioning sewage-treatment plants or overflows, leaking sewer lines, malfunctioning on-lot sewage systems, agricultural runoff, and wildlife. Beaver, deer, and waterfowl also contributed fecal-indicator bacteria to receiving waters. Because urban basins including Thompson Run and Turtle Creek contained impervious areas engineered with drainage controls, stormwater runoff can transport fecal matter associated with litter, domestic pets, and wildlife. Coliform concentrations in urban stormwater were consistent with those reported in sewage treatment plant effluent (U.S. Environmental Protection Agency, 2001).

\section{Ohio River Subbasins}

Statistical differences between cross-sectional sampling locations were observed in fecal-indicator bacteria concentrations in water samples collected during dry-weather events only at Ohio River at Sewickley (table 8). Significant differences (90-percent confidence level) were observed in enterococci concentrations between left-bank and composite samples and between right-bank and left-bank samples in dry-weather conditions (p-values of 0.016 and 0.002 , respectively). The only other significant difference was observed in fecal coliform concentrations between right-bank and left-bank samples in dry weather with a p-value of 0.090 (table 8). Samples collected at Ohio River at Sewickley typically had higher bacteria concentrations in the left-bank samples than bacteria concentrations in right-bank or composite samples during dry-weather events. Similar to findings at Monongahela River at Pittsburgh, this is an indication that bacteria from near-shore inputs tended to hug the left bank during dry-weather conditions.

A variety of point and nonpoint sources of fecal-indicator bacteria are probably responsible for exceedences to bacteria standards and criteria at Ohio River at Sewickley during dryand wet-weather conditions. Point sources of fecal-indicator bacteria included sewer outfalls directly on the banks of the Ohio River and sewer outfalls on tributaries (fig. 7). The results of wet-weather sampling for Sawmill Run at Duquesne Heights and Chartiers Creek at Carnegie (fig. 3) indicated these streams contributed high concentrations of fecal-indicator bacteria to the Ohio River (fig. 2). However, bacteria loads coming from the tributaries appeared to be well-mixed once they reach the Ohio River at Sewickley because no statistically significant differences were observed during wet weather (table 8). Similar to the Allegheny and Monongahela River subbasins, nonpoint sources of fecal-indicator bacteria at Ohio River at Sewickley included sewage discharging to tributary streams, malfunctioning sewage-treatment plants or overflows, leaking sewer lines, malfunctioning on-lot sewage systems, agricultural runoff, and wildlife.

\section{Summary and Conclusions}

This report presents the results of a study by the Allegheny County Sanitary Authority (ALCOSAN), Allegheny County Health Department (ACHD), and the U.S. Geological Survey (USGS) to determine the concentrations of fecal-indicator bacteria in the Allegheny, Monongahela, and Ohio Rivers (Three Rivers) and selected tributaries in Allegheny County, Pittsburgh, Pa. Water-quality samples were collected and river streamflow was measured during the summer and early fall from 2001 through 2005 during dry- (72-hour dry antecedent period) and wet-weather (48-hour dry antecedent period and at least 0.3 inch of rain in a 24-hour period) conditions at five sampling sites on the Three Rivers in Allegheny County. Water samples for analysis of fecal-indicator bacteria also were collected from eight sites on four tributaries having combined sewer overflows.

Water samples were analyzed for fecal-indicator organisms including fecal-coliform, Escherichia coli (E. coli), and enterococci bacteria. The samples were collected by the USGS and analyzed by the ACHD Laboratory. At each site, left-bank and right-bank samples were collected in addition to a composite sample (discharge-weighted sample representative of the channel cross section as a whole).

Fecal-indicator bacteria were detected in most samples collected for this study; concentrations in the Three Rivers and selected tributaries frequently exceeded established recreational standards and criteria. Fecal coliform, E. coli, and enterococci bacteria were detected in 98.6, 98.5, and 87.7 percent, respectively, of the samples collected from July 2001 through August 2005. Concentrations of fecal coliform exceeded the Pennsylvania recreational water-quality standard of $200 \mathrm{col} / 100 \mathrm{~mL}$ in 63.3 percent of the samples, concentrations of $E$. coli bacteria exceeded the USEPA recreational water-quality criterion of $235 \mathrm{col} / 100 \mathrm{~mL}$ in 52.8 percent of the samples, and enterococci bacteria exceeded the USEPA recreational water-quality criterion of $61 \mathrm{col} / 100 \mathrm{~mL}$ in 46.9 percent of the samples. The maximum fecal-indicator bacteria concentrations were detected in Sawmill Run, a tributary to the Ohio River; a sample collected from Sawmill Run at Duquesne Heights following a storm from the remnants of Hurricane Ivan on September 17, 2004, con- 


\section{EXPLANATION}

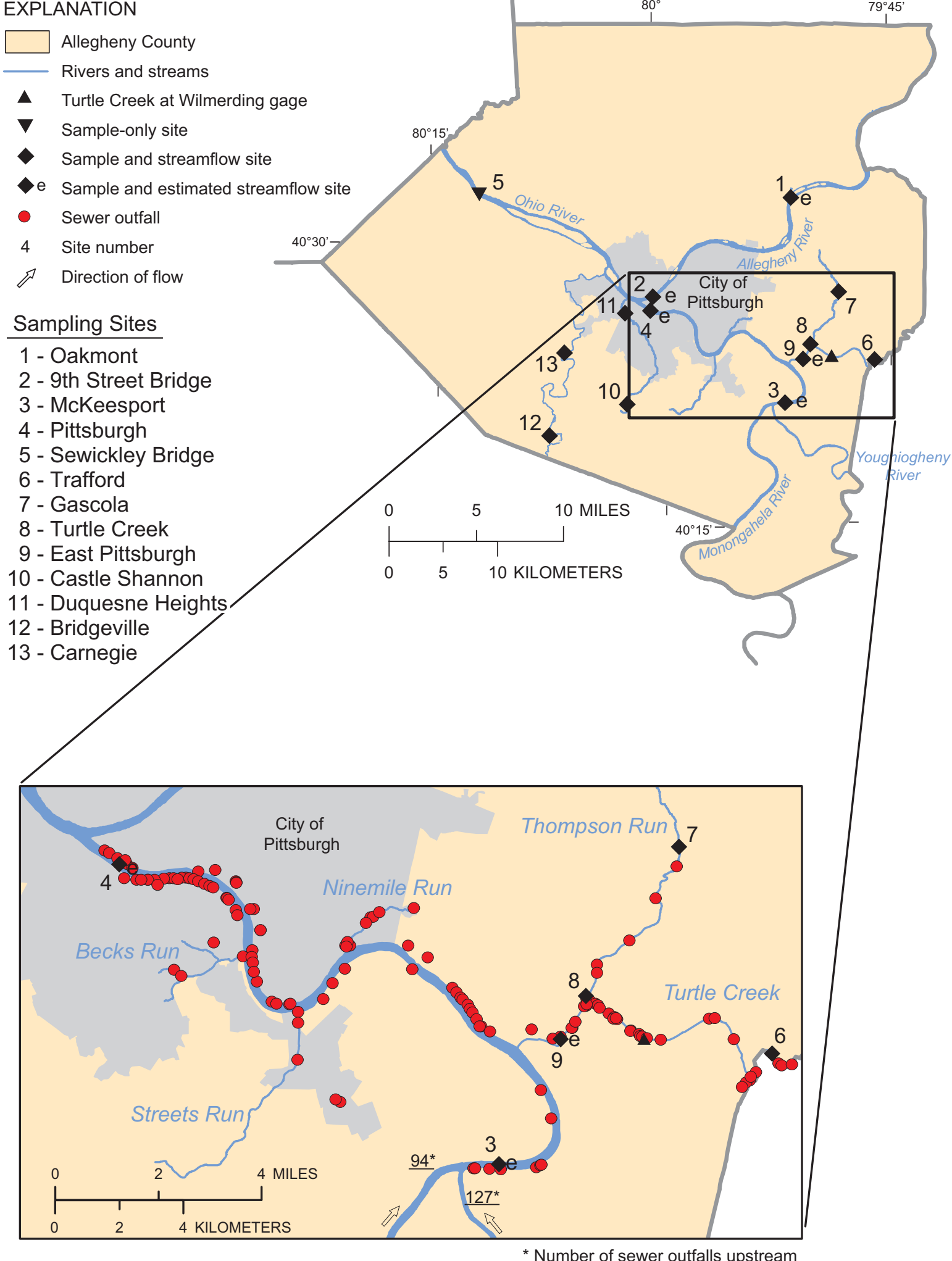

Figure 6. Locations of data-collection sites and sewer outfalls within the Monongahela River, Turtle Creek, and Thompson Run watersheds, Allegheny County, Pennsylvania. 


\section{EXPLANATION}

Allegheny County

Rivers and streams

$\Delta \quad$ Ohio River at Sewickley gage

$\nabla$ Sample-only site

- Sample and streamflow site

$\checkmark$ e Sample and estimated streamflow site

- Sewer outfall

4 Site number

Direction of flow

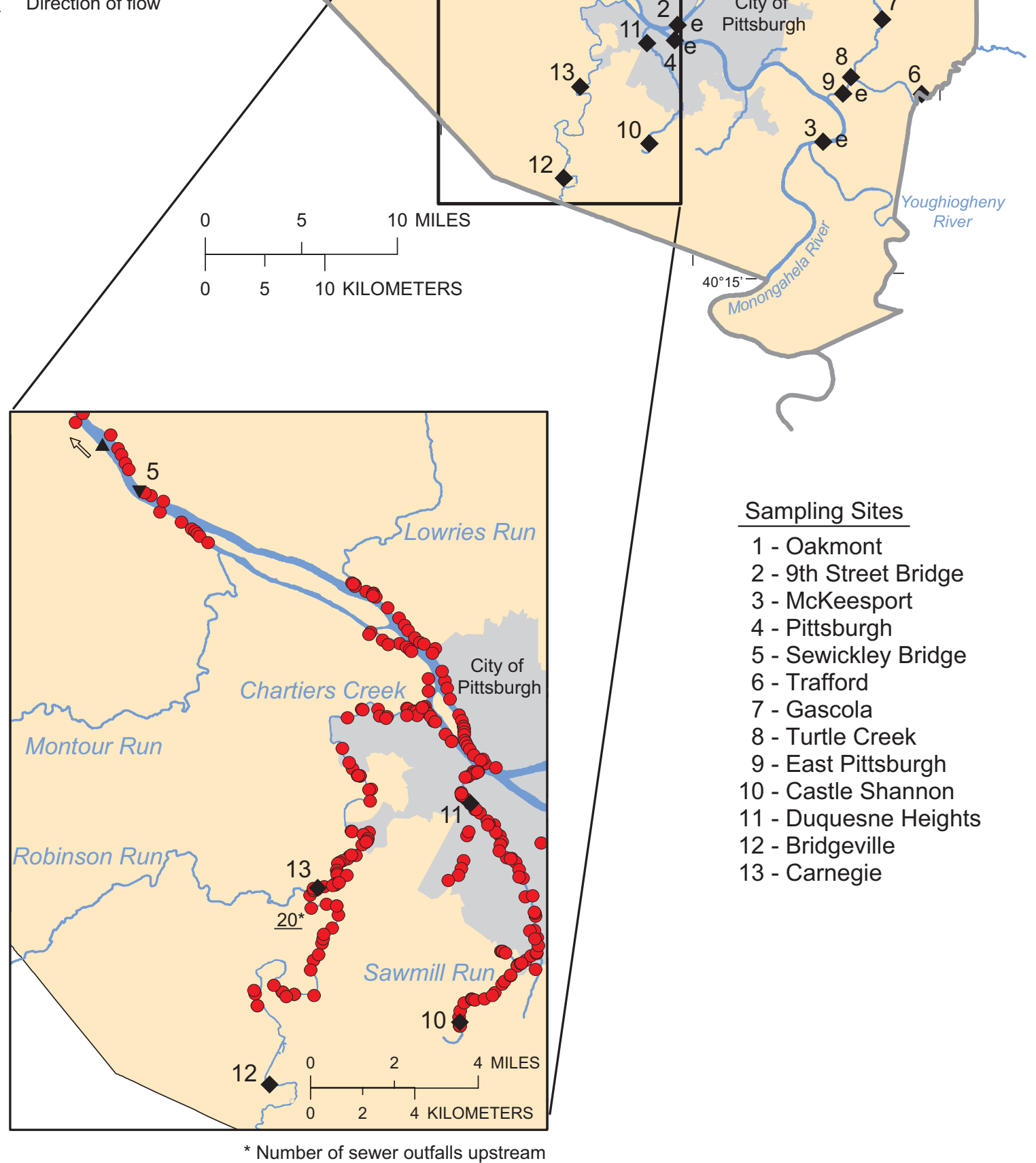

Figure 7. Locations of data-collection sites and sewer outfalls on the Ohio River and Chartiers Creek and Sawmill Run tributaries, Allegheny County, Pennsylvania. 
tained concentrations of fecal coliform, E. coli, and enterococci of $410,000,510,000$, and $180,000 \mathrm{col} / 100 \mathrm{~mL}$, respectively.

Correlation tests were done to determine if field characteristics were related to concentrations of fecal-indicator bacteria. The strongest correlations were between fecal-indicator bacteria concentrations and streamflow, specific conductance, and turbidity and generally were found in data from the tributary sites. For example, statistically significant correlations were observed between fecal coliform, E. coli, and enterococcus bacteria and specific conductance at Chartiers Creek near Bridgeville; Spearman's rho correlation coefficients were $-0.811,-0.857$, and -0.813 , respectively. Weaker correlations existed between fecal-indicator bacteria and other variables at all sites, as indicated by smaller values of Spearman's rho.

Comparisons were made between results of analyses of composite samples collected during dry- and wet-weather conditions in the Three Rivers and selected tributary sites. Overall, about 35 percent of the composite samples collected from the Three Rivers sites and 13 percent of the composite samples collected from the tributary sites had bacteria concentrations that did not exceed any established recreational water-quality standards or criteria. Median concentrations of bacteria generally were higher in the wet-weather day-one composite samples and above water-quality standards or criteria compared to the dryweather or wet-weather day-three composite samples at the Three Rivers site; median bacteria concentrations generally were above water-quality standards or criteria in the dryweather and wet-weather composite samples at the eight tributary sites. Composite samples collected at the upstream sites on the Three Rivers and on selected tributaries generally had lower median concentrations of bacteria than composite samples collected at the downstream sites during dry- and wet-weather events. Higher concentrations downstream may be caused by discharge from the large number of sewer outfalls in the reach between the upstream and downstream sites.

Comparisons also were made among concentrations of fecal-indicator bacteria and turbidity in right-bank and composite samples, left-bank and composite samples, and right-bank and left-bank samples collected during dry- and wet-weather conditions at the Three Rivers sites. More statistically significant differences in data ( 12 total -4 in dry weather, 8 in wet weather) were observed in samples collected at Allegheny River sites than at Monongahela River sites or the Ohio River at Sewickley; most differences were between bank and composite samples as opposed to differences between right-bank and leftbank samples. Bacteria concentrations at the Allegheny sites typically were higher in the bank samples than in the composite samples during dry- and wet-weather events. This finding is an indication that bacteria from near-shore inputs tended to remain near the shore, regardless of weather conditions. In samples collected at Monongahela River at Pittsburgh, significant differences were observed in enterococci bacteria concentrations during dry-weather conditions and in turbidity measurements during wet-weather conditions between left-bank and composite samples (p-values of 0.019 and 0.074 , respectively). During dry-weather conditions at Monongahela River at Pittsburgh, higher enterococci concentrations in left-bank compared to composite samples indicated that near-shore bacteria inputs tend to stay near the shoreline. During wet-weather conditions at Monongahela River at Pittsburgh, lower turbidity measurements in left-bank compared to composite samples indicated there may be a dilution effect near the shoreline as bacteria and sediment are being flushed further out into the stream channel. Statistical differences in concentrations of enterococci and fecal coliform bacteria between cross-sectional sampling locations were observed during dry-weather events only at the Ohio River at Sewickley. Concentrations of bacteria in samples from the Ohio River at Sewickley typically were higher in the left-bank samples than in the right-bank or composite samples during dry-weather events. Similar to findings at Monongahela River at Pittsburgh, this is an indication that bacteria from near-shore inputs tended to hug the left bank during dry-weather conditions.

A variety of point and nonpoint sources of fecal-indicator bacteria likely contribute to concentrations in the Three Rivers and selected tributaries. Point sources of fecal-indicator bacteria likely include sewer outfalls; nonpoint sources of bacteria likely include sewage discharging to tributary streams, malfunctioning sewage-treatment plants or overflows, leaking sewer lines, malfunctioning on-lot sewage systems, agricultural runoff, and wildlife. A study is underway between ALCOSAN, ACHD, and the USGS to determine the sources of E. coli contamination to the Three Rivers that will include the development of a water-quality model to predict bacteria concentrations. Additional data collection that would incorporate more wet-weather sampling and sampling from additional Three Rivers tributaries would also provide information helpful in defining the length of time concentrations of bacteria remain elevated after a wet-weather event.

\section{References Cited}

American Public Health Association, American Water Works Association, and Water Environment Federation, 1998, Standard methods for the examination of water and waste-water (20th ed.): Washington, D.C., American Public Health Association, $1,100 \mathrm{p}$.

Chapra, S.C., 1997, Surface water-quality modeling: New York, McGraw-Hill Publisher, Inc., 844 p.

Committee on Water Quality Improvement for the Pittsburgh Region, 2005, Regional cooperation for water quality improvement in southwestern Pennsylvania: Washington, D.C., National Research Council of the National Academies, The National Academies Press, $282 \mathrm{p}$.

Fulton, J.W., and Buckwalter, T.F., 2004, Fecal-indicator bacteria in the Allegheny, Monongahela, and Ohio Rivers, near Pittsburgh, Pennsylvania, July - September 2001: U.S. Geological Survey Scientific Investigations Report 2004-5009, $39 \mathrm{p}$. 
Helsel, D.R., 2005, Nondetects and data analysis: New Jersey, John Wiley and Sons, Inc., 250 p.

Koryak, M., and Reilly, R.J., 2000, Ninemile Run, Allegheny County, Pennsylvania-Aquatic Ecosystem Restoration Water Quality and Aquatic Life Report: Pittsburgh, Pa., U.S. Army Corps of Engineers.

Oberg, K.A., Morlock, S.E., and Caldwell, W.S., 2005, Qualityassurance plan for discharge measurements using acoustic Doppler current profilers: U.S. Geological Survey Scientific Investigations Report 2005-5183, 35 p.

Ohio River Water Sanitation Commission, 2006, Combined sewer overflow studies: accessed June 26, 2006, at http://www.orsanco.org/watqual/rec/cso.asp.

Pennsylvania Code, Title 25. Environmental protection, Chapter 93. Water quality standards, Section 93.7., Specific water quality criteria (25PaCode $\S 93.7$ ).

Rantz, S.E., 1982, Measurement and computation of streamflow-volume 1, measurement of stage and discharge: U.S. Geological Survey Water-Supply Paper 2175, 284 p.

Reilly, R.J., 2005, Integration and review of phases I, II, and III, chemical, physical, and biological data, collected from streams tributary to the Allegheny, Monongahela, and Ohio Rivers in Allegheny County, Pennsylvania, and characterization of tributary streams based on stream water quality and ecosystem health: Three Rivers Second Nature Phase IV Report, U.S. Army Corps of Engineers, Pittsburgh District, 41 p., tables and appendices.

Siwicki, R.W., 2005, Water resources data, Pennsylvania, water year 2004, vol. 3, Ohio and St. Lawrence River Basins: U.S. Geological Survey Water-Data Report PA-04-3, 337 p.
States, S., Stadterman, K., Ammon, L., Vogel, P., Baldizar, J., Wright, D., Conley, L., and Sykora, J., 1997, Protozoa in river water-Sources, occurrence, and treatment: Journal of the American Water Works Association, v. 89, no. 9, p. 74-83.

U.S. Environmental Protection Agency, 1986, Ambient waterquality criteria for bacteria--1986: Washington, D.C., Office of Water, EPA-440/5-84-002, 18 p.

U.S. Environmental Protection Agency, 1999, Combined sewer overflows-Guidance for monitoring and modeling: U.S. Environmental Protection Agency, Office of Water, EPA 832-B-99-002, variously paged.

U.S. Environmental Protection Agency, 2000, Improved enumeration methods for the recreational water quality indicators-enterococci and Escherichia coli: U.S. Environmental Protection Agency, EPA/821/R-97/004, March 2000, 53 p.

U.S. Environmental Protection Agency, 2001, Protocol for developing pathogen TMDLs: U.S. Environmental Protection Agency, Office of Water, EPA 841-R-00-002, first edition, variously paged.

U.S. Geological Survey, 1997 to present, National field manual for the collection of water-quality data: U.S. Geological Survey Techniques of Water-Resources Investigations, book 9, chaps. A1-A9, v. 2, variously paged, accessed April 13, 2006, at http://water.usgs.gov/owq/FieldManual.

U.S. Geological Survey, 2006, USGS water-quality data for Pennsylvania: accessed Dec. 12, 2006, at http://nwis.waterdata.usgs.gov/pa/nwis/qwdata. 